\title{
DEMATEL and Analytic Network Process for Evaluating Stock Trade Strategies Using Livermore's Key Price Logic
}

\author{
John Wei-Shan $\mathrm{Hu}^{1,2}$, Yi-Chung $\mathrm{Hu}^{1, *}$, Tsan-Ping Yang ${ }^{1}$ \\ ${ }^{1}$ Department of Business Administration, Chung Yuan Christian University, Taiwan \\ ${ }^{2}$ Department of Finance, Chung Yuan Christian University, Taiwan
}

Copyright $\odot 2017$ by authors, all rights reserved. Authors agree that this article remains permanently open access under the terms of the Creative Commons Attribution License 4.0 International License

\begin{abstract}
Jesse L. Livermore was one of the World's greatest stock traders on Wall Street in the early twentieth century. He was also regarded as "the most fabulous US stock trader" by Time magazine. This study combined Livermore's financial key price logic with the decisionmaking trial and evaluation laboratory (DEMATEL) and analytic network process (ANP) methods (D-ANP). This investigation attempted to find the key factors and their cause- effect relationships. This study then combined the key factors with Livermore's key price logic to develop two strategies for forecasting the trend in the Taiwan Stock Exchange Capitalization Weighted Stock Index (TAIEX). This work also compared these two strategies with another strategy that did not incorporate Livermore's logic in order to determine the optimum strategy. This study then compared the return using the optimum strategy with that based on TAIEX futures during the test period. The process was performed as follows: First, integrated questionnaires were distributed to 12 financial experts on Taiwan's stocks and futures markets in order to select $3 / 7$ key factors that might affect Taiwan's stock markets. (i.e., "net buying/selling volume by foreign institutional investors", "total market trading volume," "predictions of future trends by foreign institutional investors"). The key factors were incorporated into Livermore's key price logic to develop two trading strategies (Strategies A and B). In addition, Strategy $\mathrm{C}$ was simply developed using the D-ANP method and the three factors selected by financial experts. The major variables considered by Livermore (uptrend and downtrend) were not selected as the key factors by the financial experts, so Strategy C did not incorporate Livermore's logic. Ten transactions were examined during the period from January 1, 2013 to December 31, 2014 (the pre-test period), and only Strategy $\mathrm{C}$ was found to be effective because its winning percentage (WP) exceeded 50\% (60\%), whereas Strategies A and B had WPs less than 50\% (30\% each). Eight adjustments were then made to Strategy $C$ to develop an amended Strategy C. The amended Strategy $\mathrm{C}$ was then tested against TAIEX futures during the period from January 1, 2015 to June 30, 2015 (test period). The empirical result obtained
\end{abstract}

demonstrated that the amended Strategy $\mathrm{C}$ performed better than TAIEX futures during both periods (pre-test period and test period), as well as outperforming Strategies A and B, which were developed based on Livermore's key price logic.

Keywords Analytic Network Process, DEMATEL, Foreign Institutional Investor, Jesse L. Livermore, Key Price Logic, Mechanistic Trading and Trading Strategy, TAIEX

\section{Introduction}

Over the past two decades, financial derivatives have become very popular instruments in Taiwan. The Taiwan Stock Exchange Capitalization Weighted Stock Index (TAIEX) has even become the underlying asset of futures that are selected by investors for hedging purposes.

Time magazine described Jesse L. Livermore (July 26, 1877 to November 28,1940 ) as the "most fabulous US stock trader'. Livermore progressed from office boy to a Wall Street legend, where his victories and disasters, and the lessons he learned about trading, are probably the most fascinating story associated with Wall Street. Even today, various stock and commodity traders owe Jesse L. Livermore a great debt of gratitude for sharing his experience. Livermore argued that there is nothing new on Wall Street or in stock speculation. Thus, what happened in the past will happen again and again because human nature does not change, and human emotion always overcomes intelligence. Livermore also emphasized that the key factor required for sustained success is "experience." The techniques that he made public have endured for almost a century. His trading rules earned him millions of dollars for as long as he remained faithful to them (Smitten, 2001).

This study attempted to combine the decision making trial and evaluation laboratory (DEMATEL) and analytic network process (ANP) methods (i.e., D-ANP method) to determine the mutual correlations among each factor considered. 
The objectives of this investigation were as follows: (1) to use the D-ANP method to identify the key factors and their cause- effect relationships, (2) to combine the key factors with Livermore's key price logic to develop two strategies for forecasting the trend in TAIEX; (3) to compare these two strategies with another D-ANP strategy that does not incorporate Livermore's logic in order to determine the optimum strategy and (4) to compare the return on the optimum strategy with that on TAIEX futures during the test period.

\section{Literature Review}

This investigation classified the relevant studies into two categories: (1) articles on trading techniques, and (2) articles on DEMATEL and ANP.

Among the studies of trading techniques, Brock, Lakonishok, and LeBaron (1992) tested two of the simplest and most popular trading rules, i.e., based on the moving average and breaking out of the trading range, by applying them to data from 1897 to 1986 . They extended standard statistical analysis using bootstrap techniques. Their results supported these technical strategies.

Bessembinder and Chan (1995) found that some of the simplest forms of technical analysis were quite effective in the emerging markets of Malaysia, Thailand and Taiwan. However, their associated rules had less explanatory power when applied to more developed markets such as those of Hong Kong and Japan. On average, they found that the mean percentage changes in stock indices on days when the rules yielded buying signals exceeded the means on days when the rules yielded selling signals by $0.095 \%$ per day or approximately $26.8 \%$ on an annualized basis.

Livermore (1940) offered traders their first account of his famously tight-lipped operation's trading system. Livermore interweaved fascinating autobiographical and historical details with step-by-step guidance on: (a) reading market and stock behaviors, (b) analyzing leading sectors, (c) market timing, (d) money management, and (e) emotional control. Livermore's money- management rules comprise: (1) don't lose your stake, (2) always establish a stop, (3) keep cash in reserve, (4) let the position ride, and (5) take the profits in cash.

Since Livermore did not have the convenience of modern charts to graph his price patterns, but instead he tracked simple price patterns in a ledger. Livermore classified market trends as (1) uptrend, (2) natural reaction, (3) natural rally, (4) secondary reaction, (5) secondary rally and (6) downtrend.

Smitten (2001) introduced Jesse Livermore as follows: "Livermore always considered himself a market student who occasionally traded correctly. Livermore's actions were simply a result of his entire mind at work - distilling facts; churning information, recalling prior events; reacting to current events; watching his fellow traders; and most of all, relying on his own judgment, not the judgment of others."

Boik $(2004,2006)$ described Livermore as follows: "Jesse Livermore followed the general trend of the market to do well." The key factors responsible for the success of Livermore and four of the other greatest stock traders of all time are as follows: (1) trade only according to the identical trend in the market, (2) stay out of flat or directionless markets, (3) pyramid one's winning positions to compound one's returns, (4) adhere to a strict loss-cutting policy, (5) stay focused on only a handful of stocks at a time, usually 10 or less, and (6) trade only the leaders from the leading industries.

Among the studies on DEMATEL and ANP, Saaty (1986, 1996, 2001) presented the ANP theory as a relatively new multiple criteria decision-making (MCDM) method. ANP is a widely- used method that considers the interdependencies among factors and determines their relative importance (Saaty and Takizawa, 1986; Satty 2001 Chung et al., 2005; $\mathrm{Hu}, 2010)$. ANP has been successfully utilized in many fields (e.g. Sekitani and Takahashi, 2001; Meade and Presley, 2002; Kionsita, 2003; Leung, Hui and Zheng, 2003; Shee, Tzeng and Tang, 2003; Niemira and Saaty, 2004; Yurdakul, 2004; Chung, Lee and Pearn, 2005; Coulter and Sarkis, 2005; Tesfamuriam and Lindberg, 2005; Kahraman, Ertay and Buyukozkan, 2006). However, the treatments of the inner dependences in studies of ANP are usually incomplete. Indeed, a serious problem affects ANP because if there are too many criteria involving pairwise comparisons, then the time required for pairwise comparisons increases substantially. Moreover, it is not easy to achieve consistency (Hu and Tsai, 2006), especially for a matrix with high order, because of the influence of the limited capacity of human thinking and the shortcomings of a one to nine scale ( $\mathrm{Xu}$ and Wei, 1999). The DEMATEL method can be used for researching and solving complex and intertwined groups of problems. The end product of the DEMATEL process is a visual representation (a causal diagraph map), which allows researchers to organize their actions in the world. DEMATEL can be used to handle the inner dependences among a set of criteria. (Gabus and Fontela, 1972 and 1973; Fontela and Gabus, 1976; Hori and Shimizu, 1999; Tzeng, Chiang and Li, 2007; Li and Tzeng, 2009; Shieh, Wu and Huang (2010); Ho et al., 2011; Yang and Tzeng, 2011; Vujanavic et al., 2012; Wang and Tzeng, 2012; Chiu et al., 2013; Oh Yang et al., 2013; Hu et al., 2015). To solve the problems mentioned above, Oh Yang et al. (2008) used the D-ANP method to directly handle the total influence matrix generated by DEMATEL as the unweighted supermatrix for ANP, thereby avoiding troublesome pairwise comparisons. Similar to ANP, the relative weights of individual factors can be obtained by generating a limiting supermatrix.

ANP or D-ANP has been applied successfully to solve various real-world problems (Tzeng and Huang, 2011), such as forecasting a financial crisis (Niemira and Saaty, 2004), selecting a favorable $\mathrm{KM}$ strategy ( $\mathrm{Wu}, 2008)$, selecting projects to improve healthcare (Herat et al., 2012) electronic 
commerce (Chiu et al., 2013), and system evaluation (Hu et al., 2015). Due to the effectiveness of DEMATEL and ANP at supporting decision making, this study employed D-ANP to identify determinants for evaluating stock trading strategies.

\section{Methods}

This study combined two strategies with Livermore's financial key price logic using DEMATEL and ANP. D-ANP is a version of DEMATEL based on ANP. ANP is a general form of the analytic hierarchy process (AHP), which is used in MCDM analysis. AHP structures a decision problem as a hierarchy with goal, decision criteria, and alternatives, whereas the ANP feedback method replaces the hierarchy with a network. Both use pairwise comparisons to measure the weights of the components of the structure, and to rank the alternatives for decision making. However, many decision problems cannot be structured hierarchically because they involve interactions and dependences among higher level elements in a hierarchy (Saaty and Özdemir, 2005; Görener, 2012). ANP permits complex interrelationships among decision levels and attributes (Yüksel and Dağdeviren 2007), where the ANP scheme comprises the following four major steps (Saaty, 1996, 2005; Chuang et al., 2005, Saaty and Vargas, 2006; Yüksel and Dağdeviren, 2007; Görener, 2012).

Step 1: Model construction and problem structuring: the decision problem should be stated clearly and decomposed into a rational system, such as a network.

Step 2: Pairwise comparison matrices and priority vectors: in ANP, pairs of decision elements for each cluster are compared in terms of their importance relative to the associated control criteria. The interdependencies among criteria in a cluster must also be studied in a pairwise manner, where the effect of each element on other elements can be represented using an eigenvector.

Step 3: Supermatrix formation: for each control criterion, construct the supermatrix by sorting the clusters in numerical order and sort all elements in each cluster both vertically on the left and horizontally at the top. A supermatrix is a partitioned matrix, where each matrix segment represents a relationship between two nodes in a system (Meade and Sarkis, 1999). To obtain the global priorities in a system with interdependent drivers, the local priority vectors are entered in the corresponding columns of the matrix.
The weights derived are then applied to the elements of the corresponding column blocks in the supermatrix. The weight is zero when no influence exists. Therefore, a weighted column stochastic supermatrix is obtained.

Step 4: Selecting the best alternatives: first, compute the limiting priorities of the supermatrix, and then synthesize the limiting priorities of the criteria and alternatives. Finally, select the best alternatives.

\section{DEMATEL Structure}

The DEMATEL method developed by the Science and Human Affairs Program of the Battelle Memorial Institute of Geneva is used for analyzing and solving groups of complicated and interconnected problems. DEMATEL is a powerful method that helps to form a structural model, which allows researchers to plan and solve problems visually. In this method, researchers may divide various elements into a group of causes and a group of effects in order to elucidate relationships visually with a causal diagram. Various experts are invited to discuss the relationships and criteria related to each factor as well as their degree of importance, and to score the relationships and among criteria using the DEMATEL method. The DEMATEL method was used in the present study to elucidate the analytical structure of the components of each factor as well as the directions and intensities of the direct and indirect relationships between well-defined components. To limit the loss of information as a consequence of the DEMATEL method, an acceptable causal diagraph is drawn. Causal diagraphs are more useful than directionless graphs, because they can express the directed relationship among sub-systems.

It was reasonable to employ the D-ANP method to evaluate stock trading strategies because the complete decision structure was built using the well-known Delphi method and a direct influence matrix among factors was then constructed to indicate the degree of impact between each pair of factors.

Delphi method is usually employed in forecasting and policy-making (Gordon and Helmer, 1964; Turoff and Hiltz, 1996 and Bologin; 2001). This method was used through a sequence of questionnaires to elicit prediction from a panel of experts. The experts answered questionnaires in two or more rounds. After each round, a summary of responses would be fed back to the respondents before they reply to each succeeding round of questionnaires. 


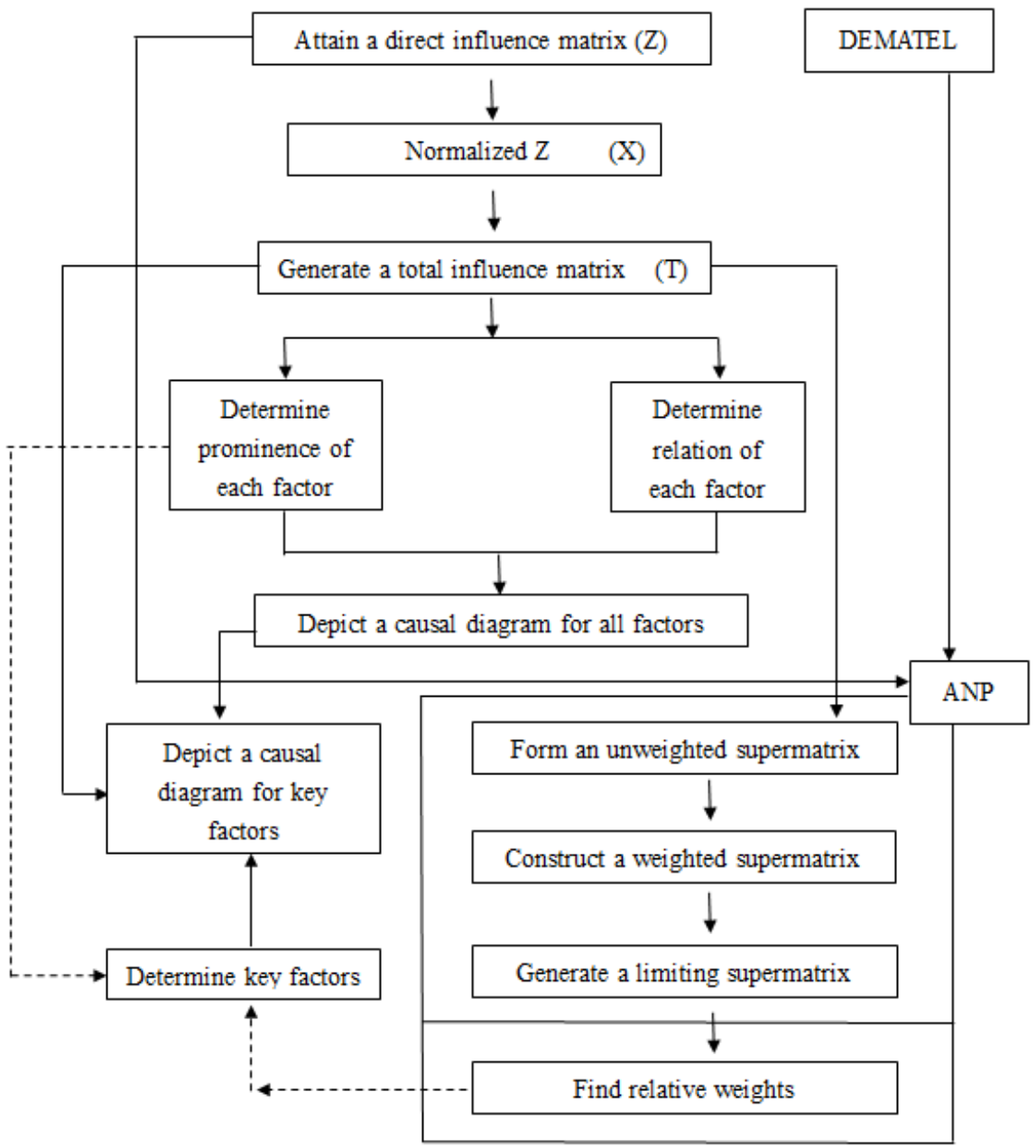

Figure 1. The proposed framework of DEMATEL-based ANP method.

Figure 1 depicted the proposed framework of DEMATEL-based ANP method. Twelve questionnaires were distributed to 12 financial experts so they could rank various financial factors. Expert questionnaires are used often in the D-ANP method. The knowledge of financial experts was used to improve our understanding of the component elements and their relationships. D-ANP method was then utilized to rank the factors in order of importance.

To elucidate the mutual influences among elements, the 12 financial experts were asked to make a series of pairwise comparisons. All 12 financial experts are the decisionmakers who were familiar with the contents of the questions and they had at least three trading experience. To aggregate their assessments, the geometric mean method was used for the ANP, while the arithmetic method was computed for the DEMATEL. After aggregation, the direct-relation matrix (Table 1) was obtained and this matrix was employed to obtain the causal diagram of the "criteria" cluster (Figure 2). Hence, the inner dependence matrix (Table 2) was obtained using DEMATEL. The unweighted supermatrix obtained is presented in Table 3.

The D-ANP method was applied according to the following seven main steps:

\section{Step 1: Determining the direct influence matrix}

This study obtains a direct influence matrix $\mathrm{Z}$ as shown in Table 1.

Table 1. Direct influence matrix

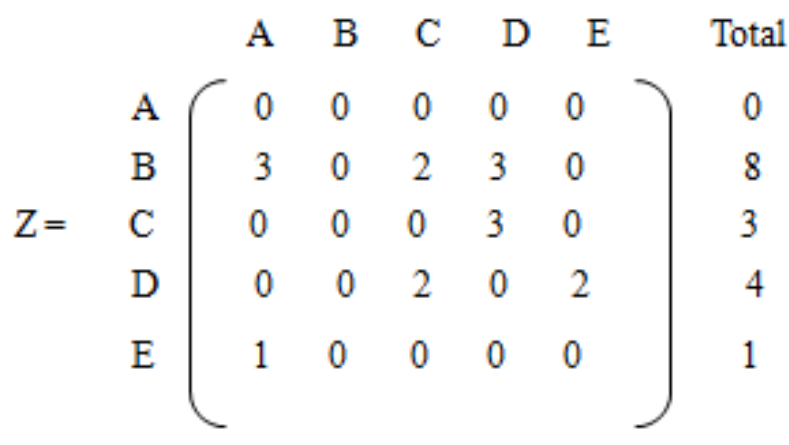

where $a_{i j}$ represents the degree to which factor $i$ affects factor $j$, and the diagonal elements are assumed to be zero.

The relationship between factors are quantified using a comparison scale with four levels: 0 (no influence), 1 (low influence), 2 (high influence) and 3 (strong influence).

Total scores for factors $\mathrm{A}$ and $\mathrm{E}$ are 0 and 1, respectively, which suggests that factors $\mathrm{A}$ and $\mathrm{E}$ have no influence or 
little influence on other factors, and thus this study considered that these two factors had much less influence than other three factors, so this work excluded these two factors subsequently.

\section{Step 2: Normalizing the direct influence matrix}

The direct influence matrix $\mathrm{Z}$ is normalized to yield the normalized relation matrix $\mathbf{X}$ using $\lambda=1 / \max _{1 \leqq_{\mathrm{i} \leqq \mathrm{n}}}\left(\sum_{j=1}^{n} Z_{i j}\right)$. Each factor in the matrix is multiplied by $\lambda$. The maximum value in Table 1 is 8 (the $B$ row), so $\lambda$ equals $1 / 8$.

Table 2. Normalized relation matrix

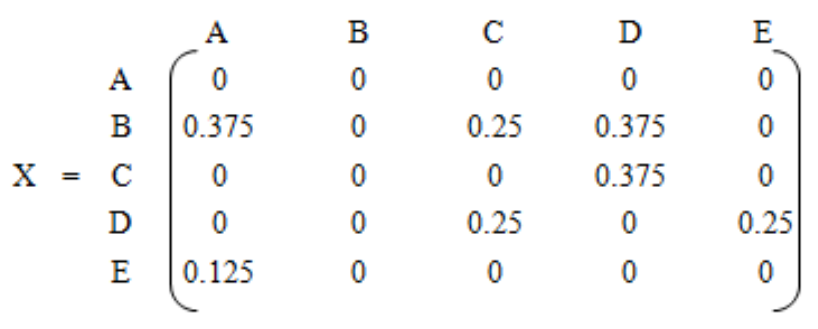

\section{Step 3: Deriving the total influence matrix}

The total influence matrix $\mathrm{T}$ is obtained by normalizing the direct-influence matrix and imposing the limit $\mathrm{x}^{\mathrm{k}}=0$, as follows.

$$
\mathbf{T}=\lim _{\mathrm{k} \rightarrow \infty}\left(X+X^{2}+\ldots+X^{k}\right)=X(I-X)^{-1} .
$$

\begin{tabular}{|c|c|c|c|c|c|c|c|}
\hline & A & B & $\mathrm{C}$ & D & E & $\begin{array}{l}\text { Dominance } \\
\text { (D) }\end{array}$ & $\begin{array}{c}\text { DEMATEL } \\
\text { Ranking }\end{array}$ \\
\hline A & 0 & 0 & 0 & 0 & 0 & 0 & 5 \\
\hline B & 0.391 & 0 & 0.379 & 0.517 & 0.129 & 1.416 & 2 \\
\hline $\mathrm{T}=\mathrm{C}$ & 0.013 & 0 & 0.103 & 0.414 & 0.103 & 0.633 & 3 \\
\hline D & 0.034 & 0 & 0.276 & 0.103 & 0.276 & 0.689 & 1 \\
\hline E & 0.125 & 0 & 0 & 0 & 0 & 0.125 & 4 \\
\hline Reciprocal (R) & 0.563 & 0 & 0.758 & 1.034 & 0.508 & & \\
\hline
\end{tabular}

Table 3. Total influence matrix

The sum of rows and the sum of columns are denoted as the vectors $\mathrm{D}$ (dominance or strength of effect) and $\mathrm{R}$ (reciprocal degree affected), respectively. Thus, the "prominence" is obtained by adding D to R. A larger prominence corresponds to more important factors. "D-R" is the "relation". If the "relation" is positive, then the factor is likely to affect other factors and it is referred to as a "cause". If the "relation" is negative, then the factor is likely to be affected by other factors and is referred to as an "effect."

Prominence $(\mathrm{D}+\mathrm{R})$ for each factor was calculated as follows:

Prominence of factor A: $0+0.563=0.563$;

Prominence of factor B: $1.416+0=1.416$;

Prominence of factor C: $0.633+0.758=1.391$;

Prominence of factor D: $0.689+1.034=1.723$;

Prominence of factor E: $0.125+0.508=0.633$;

Relation of factor A: $0-0.563=-0.563$ (effect);

Relation of factor B: $1.416-0=1.416$ (cause);

Relation of factor C: $0.633-0.758=-0.125$ (effect);
Relation of factor D: 0.689-1.034= -0.345 (effect); Relation of factor E: $0.125-0.508=-0.383$ (effect);

It shows that the top three prominent factors are D (1.723), B (1.416), and C (1.391).

\section{Step 4: Obtaining the threshold value}

A threshold value of 0.1 is set to filter out the obvious effects, as shown in Table 4.

Table 4. After applying the threshold value

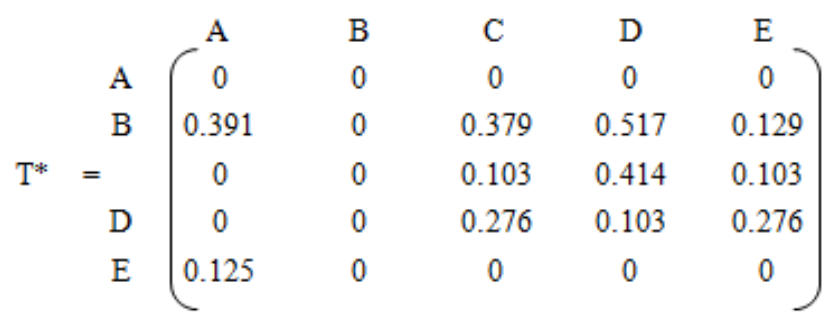

Step 5. Normalizing each row of the unweighted supermatrix to obtain the weighted supermatrix

Tzeng and Huang (2011) used the total influence matrix as the unweighted supermatrix and normalized the total influence matrix to obtain the weighted supermatrix $\mathrm{W}$ for ANP. The supermatrix is a partitioned matrix, where each matrix segment represents a relationship between two models clusters in a system. (Meade and Sarkis, 1999).

Table 5. Weighted supermatrix

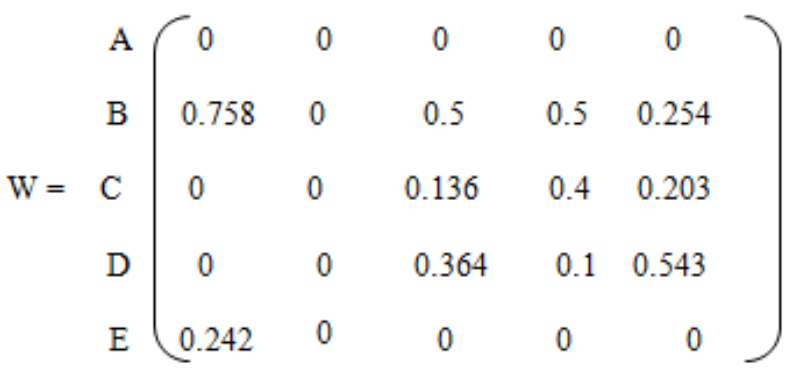

\section{Step 6. Generating the limiting supermatrix from the weighted supermatrix}

Finally, $\mathrm{W}$ is multiplied by itself many times until convergence to obtain the limiting supermatrix $\mathrm{W}^{*}$ and the global weights of all the factors.

Table 6. Limiting supermatrix

W* = A $=$ B

The top three weights of the obtained supermatrix are 
those of B (0.758); C (0.3) and D (0.2). Factors A and E did not have any effect in the ANP method.

Table 7 summarizes the importance rankings.

The ranking of the factors by importance based on the prominences generated by DEMATEL and that based on the relative weights obtained by D-ANP were inconsistent, so the final importance rankings of the factors, (i.e., the overall rankings) in Table 7, were obtained as described by $\mathrm{Hu}$ et al., (2005).

Table 7. Summary of the importance rankings

\begin{tabular}{ccccc} 
Factors & $\begin{array}{c}\text { ANP } \\
\text { Rankings }\end{array}$ & $\begin{array}{c}\text { DEMATEL } \\
\text { Rankings }\end{array}$ & $\begin{array}{c}\text { Sum of Two } \\
\text { Rankings }\end{array}$ & $\begin{array}{c}\text { Overall } \\
\text { ranking }\end{array}$ \\
\hline A & 4 & 5 & 9 & 5 \\
B & 1 & 2 & 3 & 1 \\
C & 2 & 3 & 5 & 3 \\
D & 3 & 1 & 4 & 2 \\
E & 4 & 4 & 8 & 4 \\
\hline
\end{tabular}

Factors B, D and C are the key factors.

Table 7 shows that factor B is extremely important; factor $\mathrm{D}$ is highly important, factor $\mathrm{C}$ is moderately important, factor $\mathrm{E}$ is relatively unimportant, and factor $\mathrm{A}$ is the least important. Therefore, B, D and C are the key factors.

\section{Step 7. Generating the causal diagraph of key factors}

Given that the key factors are $B, C$, and $D$, this study generated a causal diagraph of the three factors, selected from the total influence matrix as shown in Figure 2.

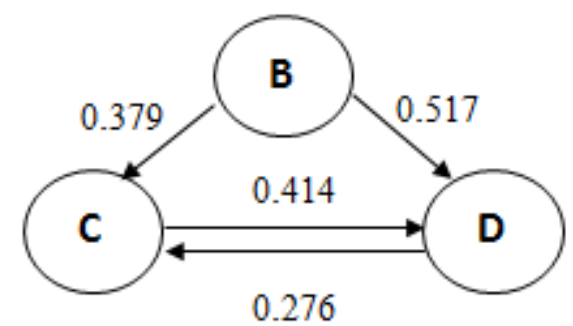

Figure 2. A Causual Diagraph of Three Key Factors

As shown in the causal diagraph between factors B, C, and D mutually interact. Moreover, investors should improve factor B because doing so facilitates improvements in $\mathrm{C}$ and D. In addition, B is categorized as a "cause", whereas both C and D are categorized as "effects".

\section{Trading strategy and trading period}

Based on the total rankings in Table 7, we employed Turtle's selection process, as proposed by Faith (2007), to trade TAIEX futures in Taiwan. Two trading strategies (A and B) were combined with Jesse L. Livermore's key price logic, whereas Strategy C did not incorporate Livermore's logic. The optimum strategy for the period from January 1, 2013 to December 31, 2014 (the pre-test period) was identified. The optimum strategy was then applied to the period from January 1, 2015 to June 10, 2015 (the test period) to test its effectiveness. The TAIEX futures were assumed to include no basic meaning that the spot price at a particular time equals the corresponding futures price. Only TAIEX futures can be bought and not the TAIEX, while the TAIEX follows TAIEX futures, so TAIEX futures were used to represent the TAIEX.

(1) Leverage effect: The minimum initial margin of TAIEX futures was NT $\$ 83,000$, so the average of the TAIEX in 2013 and 2014 was 8,544.21 (points). If one point is worth NT $\$ 200$, then the initial TAIEX futures price was NT $\$ 1,708,842$. To facilitate the subsequent calculations, we used NT $\$ 1,700,000$ instead of NT $\$ 1,708,842$. Therefore, the maximum leverage was 20.5 times $(=\mathrm{NT} \$ 1,700,000 /$ NT $\$ 83,000)$.

(2) Half of the maximum leverage (i.e., 10 times was used to calculate each amount invested as NT $\$ 170,000(=$ NT $\$ 1,700,000 / 10)$.

(3) The cost of each trade is the sum of the trading commission (NT\$50- NT\$200) and the trading tax $(0.002 \%)$. The trading commission was assumed to be NT $\$ 116$ and the trading tax was $\$ 34(\$ 1,700,000$ $\times 0.002 \%$ ); hence, the round-trip transaction costs were $\$ 300$.

To determine the winning percentage (WP) for each strategy, 10 pre-test transactions were conducted. If the WP for a strategy was too low (below $50 \%$ ), then that strategy was abandoned. This withdrawing policy is a trading custom for any reasonable trader, and it also conforms to the strict loss- cutting policy proposed by five great stock traders.

This study then tested two strategies based on Livermore's logic as well as another strategy based on the D-ANP method and the selected results given by 12 financial experts, as follows:

\section{Strategy A}

Strategy A combines the uptrend /downtrend of Jesse L. Livermore with the top key financial factor for two consecutive days. The investor buys (sells) TAIEX futures on the following day, and then holds the position until the day when the closing price falls (breaks) through the five-day MA line (10-day MA line), or the conditions are not fulfilled for two days continuously. The investor then closes out the transaction on the following day to stop profit (loss). A leverage of 10 times is used.

\section{Strategy B}

Strategy B combines the uptrend /downtrend of Jesse L. Livermore with the conditions where the top three financial factors are fulfilled. The investor buys (sells) TAIEX futures on the following day and holds the position until the day when the closing price falls (breaks) through the five-day MA line (10-day MA line). The investor then closes out the transaction to stop profit (loss). A leverage of 10 times is used. 


\section{Strategy C}

Strategy C simply uses the D-ANP method with the conditions for the top key financial factor is fulfilled for two consecutive days, plus the conditions for either the second or third key financial factor are fulfilled. The investor then buys (sells) TAIEX futures on the following day and holds the position until the closing price of TAIEX futures falls (rises) through the five-day MA line (10-day MA line). The investor then closes out the transaction to stop profit (loss). A leverage of 10 times is used. D-ANP is a method for making policy decisions rather than a statistical testing method, so it is not necessary to check whether the results are statistically significant.

\section{Empirical Results}

The seven factors listed in Table 8 influenced the trends in TAIEX futures.

Table 8. Definitions of seven influential factors and related assumptions

\begin{tabular}{|c|c|c|}
\hline Symbol & Factor Name & Definition of Factor \\
\hline A & TAIEX & Taiwan Stock Exchange Capitalization Weighted Stock Index. \\
\hline B & $\begin{array}{c}\text { Volume bought/sold by foreign } \\
\text { institutional investors (FIIs) }\end{array}$ & TAIEX rises /falls 35 points (0.4375\%) \\
\hline C & Increase in market trading volume & Total trading volume exceeds the 20-day average trading volume. \\
\hline D & TAIEX reaches an extreme value & $\begin{array}{c}\text { Maximum point of the TAIEX is 9,276.29 and the minimum point is 7,909.52 } \\
\text { during the study period. }\end{array}$ \\
\hline E & Trend forecast by FII. & $\begin{array}{c}\text { When the open interest of FII reaches } 10,000, \text { this suggests that the viewpoint of the } \\
\text { FII regarding the future trend in the TAIEX is promising. }\end{array}$ \\
\hline F & Nine-day K and D- indices of TAIEX & Nine-day K- and D- indices reach 20 or 80. \\
\hline G &
\end{tabular}

Fifteen questionnaires were distributed to financial experts and 12 were recovered. The following D-ANP ranking method was then used to rank the degree of importance.

\section{Step 1: Obtaining direct influence matrix}

The direct influence matrix was calculated by averaging the sum of the values in the matrices obtained from the 12 returned questionnaires.

Table 9. Direct influence matrix Z

\begin{tabular}{|c|c|c|c|c|c|c|c|c|}
\hline \multirow{9}{*}{$Z=$} & Average & A & B & $\mathrm{C}$ & $\mathrm{D}$ & E & $\mathrm{F}$ & G \\
\hline & A & 0.0000 & 1.0000 & 1.7500 & 2.1667 & 1.5000 & 2.0000 & 1.1667 \\
\hline & $\mathrm{B}$ & 2.4167 & 0.0000 & 2.1667 & 2.4167 & 1.7500 & 2.0000 & 1.3333 \\
\hline & $\mathrm{C}$ & 2.8333 & 2.7500 & 0.0000 & 3.1667 & 2.0000 & 2.5833 & 1.4167 \\
\hline & $\mathrm{D}$ & 2.8333 & 2.5000 & 2.9167 & 0.0000 & 2.1667 & 2.4167 & 1.1667 \\
\hline & $\mathrm{E}$ & 2.5833 & 2.0833 & 2.3333 & 2.5000 & 0.0000 & 1.9167 & 0.5833 \\
\hline & $\mathrm{F}$ & 3.0833 & 2.4167 & 2.9167 & 2.5000 & 2.0833 & 0.0000 & 1.1667 \\
\hline & $\mathrm{G}$ & 1.5833 & 1.6667 & 1.1667 & 1.1667 & 1.1667 & 1.1667 & 0.0000 \\
\hline & Total & 15.3332 & 12.4167 & 13.2501 & 14.4168 & 10.6667 & 12.0834 & 6.8334 \\
\hline
\end{tabular}

Step 2: Normalizing the direct influence matrix $\mathbf{Z}$

Since $\lambda=1 / \max 1 \leqq i \leqq n\left(\sum_{\mathrm{ij}}\right)$ and the maximum value in Table 9 is 15.3332 (column A), then $\lambda=1 / 15.3332=0.0652$. Table 10 shows the normalized direct influence matrix X.

Table 10. Normalized direct influence matrix X

\begin{tabular}{|c|c|c|c|c|c|c|c|c|}
\hline \multirow{8}{*}{$X=$} & Normalizing & A & $\mathrm{B}$ & $\mathrm{C}$ & $\mathrm{D}$ & $\mathrm{E}$ & $\mathrm{F}$ & G \\
\hline & A & 0.0000 & 0.0652 & 0.1141 & 0.1413 & 0.0978 & 0.1304 & 0.0761 \\
\hline & B & 0.1576 & 0.0000 & 0.1413 & 0.1576 & 0.1141 & 0.1304 & 0.0870 \\
\hline & $\mathrm{C}$ & 0.1848 & 0.1793 & 0.0000 & 0.2065 & 0.1304 & 0.1685 & 0.0924 \\
\hline & $\mathrm{D}$ & 0.1848 & 0.1630 & 0.1902 & 0.0000 & 0.1413 & 0.1576 & 0.0761 \\
\hline & $\mathrm{E}$ & 0.1685 & 0.1359 & 0.1522 & 0.1630 & 0.0000 & 0.1250 & 0.0380 \\
\hline & $\mathrm{F}$ & 0.2011 & 0.1576 & 0.1902 & 0.1630 & 0.1359 & 0.0000 & 0.0761 \\
\hline & G & 0.1033 & 0.1087 & 0.0761 & 0.0761 & 0.0761 & 0.0761 & 0.0000 \\
\hline
\end{tabular}




\section{Step 3: Deriving the total influence matrix}

The total influence matrix in Table 11 was derived by multiplying each factor by itself and calculating the following limiting sum.

$$
\mathrm{T}=\lim _{\mathrm{k} \rightarrow \infty}\left(\mathrm{X}+\mathrm{X}^{2}+\ldots+\mathrm{X}^{\mathrm{k}}\right)=\mathrm{X}(\mathrm{I}-\mathrm{X})^{-1}
$$

Table 11. Total influence matrix of DEMATEL rankings

\begin{tabular}{|c|c|c|c|c|c|c|c|c|}
\hline $\begin{array}{c}\text { Total influence } \\
\text { matrix }\end{array}$ & A & B & $\mathrm{C}$ & D & $\mathrm{E}$ & $\mathrm{F}$ & $\mathrm{G}$ & $\mathrm{D}$ (Dominance) \\
\hline A & 0.4809 & 0.4557 & 0.5274 & 0.5670 & 0.4376 & 0.5083 & 0.2995 & 3.2765 \\
\hline B & 0.7213 & 0.4764 & 0.6402 & 0.6769 & 0.5263 & 0.5943 & 0.3592 & 3.9945 \\
\hline $\mathrm{C}$ & 0.8572 & 0.7232 & 0.6191 & 0.8199 & 0.6228 & 0.7178 & 0.4184 & 4.7784 \\
\hline $\mathrm{D}$ & 0.8284 & 0.6871 & 0.7533 & 0.6220 & 0.6099 & 0.6862 & 0.3912 & 4.5781 \\
\hline $\mathrm{F}$ & 0.8463 & 0.6870 & 0.7582 & 0.7673 & 0.6098 & 0.5549 & 0.3941 & 4.6175 \\
\hline G & 0.4800 & 0.4129 & 0.4121 & 0.4287 & 0.3513 & 0.3876 & 0.1860 & 2.6586 \\
\hline R (Reciprocal) & 4.9511 & 4.0474 & 4.3657 & 4.5708 & 3.5868 & 4.0458 & 2.3694 & 27.9330 \\
\hline
\end{tabular}

Prominence was obtained by adding D to R, as follows.

Prominence of factor A: $3.2765+4.9511=8.2276$

DEMATEL Ranking

Prominence of factor B: $3.9945+4.0434=8.0379$

4

Prominence of factor C: $4.7784+4.3657=9.1441$

5

Prominence of factor D: $4.5781+4.5708=9.1489$

2

Prominence of factor E: $4.0293+3.5868=7.6161$

Prominence of factor F: $4.6175+4.0458=8.6633$

6

Prominence of factor G: $2.6586+2.3694=5.0280$

3

7

To ensure that information was retained concerning the interactions among all the factors, no threshold value was imposed.

\section{Step 4: Generating the network diagram of various factors}

Figure 3 was derived based on the interactions among six factors with causal relations that exceeded 0.7.

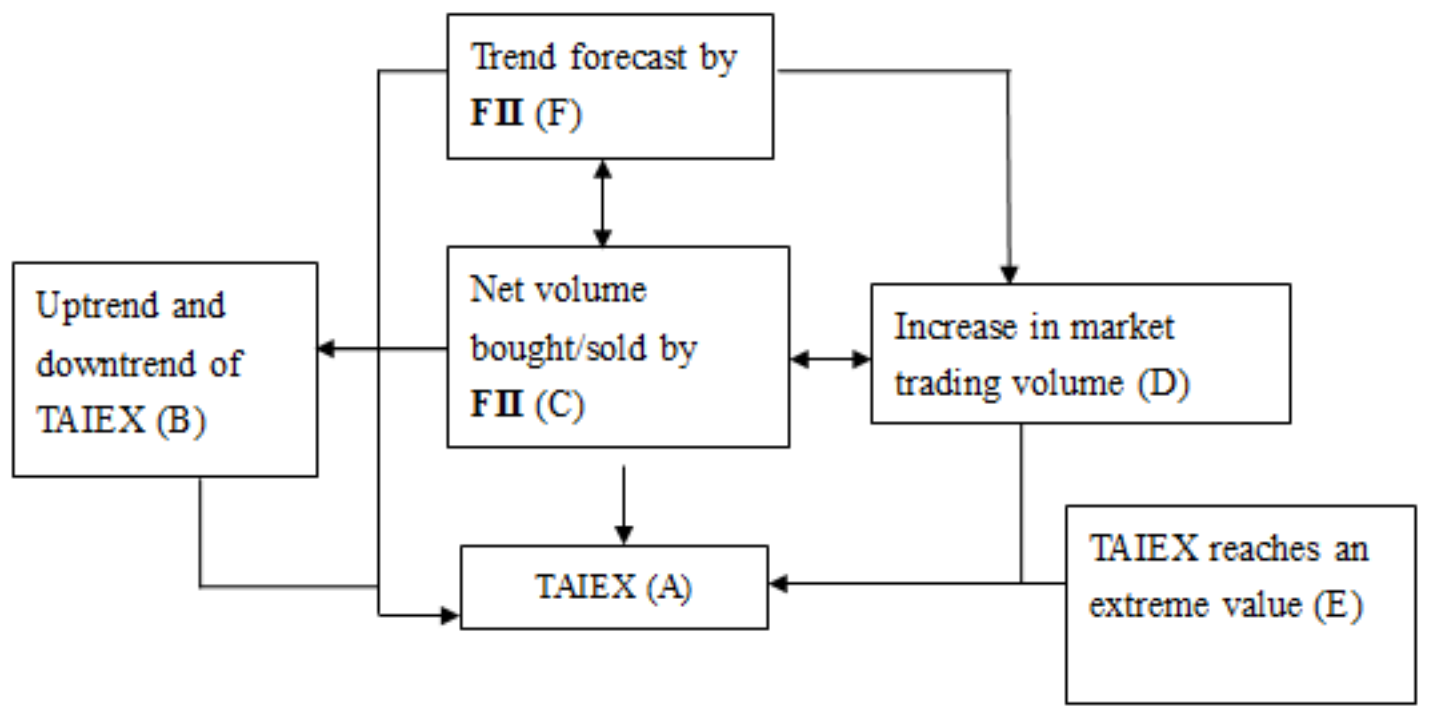

Figure 3. Causal diagram for six factors

\section{Step 5: Deriving the weighted supermatrix}

Each row in the unweighted supermatrix was normalized to obtain the weighted supermatrix in Table 12. 
Table 12. Weighted supermatrix

\begin{tabular}{|c|c|c|c|c|c|c|c|c|}
\hline \multirow{8}{*}{$\mathrm{W}=$} & $\begin{array}{l}\text { The weighted } \\
\text { supbermatrix }\end{array}$ & A & B & $\mathrm{C}$ & D & $\mathrm{E}$ & $\mathrm{F}$ & G \\
\hline & A & 0.0971 & 0.1127 & 0.1208 & 0.1241 & 0.1220 & 0.1256 & 0.1264 \\
\hline & B & 0.1457 & 0.1178 & 0.1466 & 0.1481 & 0.1467 & 0.1469 & 0.1516 \\
\hline & $\mathrm{C}$ & 0.1731 & 0.1789 & 0.1418 & 0.1794 & 0.1736 & 0.1774 & 0.1766 \\
\hline & D & 0.1673 & 0.1699 & 0.1725 & 0.1361 & 0.1700 & 0.1696 & 0.1651 \\
\hline & E & 0.1489 & 0.1486 & 0.1501 & 0.1507 & 0.1196 & 0.1475 & 0.1355 \\
\hline & $\mathrm{F}$ & 0.1709 & 0.1699 & 0.1737 & 0.1679 & 0.1700 & 0.1371 & 0.1663 \\
\hline & G & 0.0970 & 0.1021 & 0.0944 & 0.0938 & 0.0979 & 0.0958 & 0.0785 \\
\hline
\end{tabular}

\section{Step 6: Generating the limiting supermatrix}

The limiting supermatrix was generated by multiplying the ANP weighted supermatrix by itself multiple times until convergence. (Table 13).

Table 13. Limiting supermatrix

\begin{tabular}{|c|c|c|c|c|c|c|c|c|c|}
\hline \multirow{8}{*}{$\mathrm{W}^{*}=$} & $\begin{array}{c}\text { Limiting } \\
\text { Supermatrix }\end{array}$ & A & B & $\mathrm{C}$ & $\mathrm{D}$ & E & $\mathrm{F}$ & $\mathrm{G}$ & $\begin{array}{c}\text { ANP } \\
\text { Ranking }\end{array}$ \\
\hline & A & 0.1189 & 0.1189 & 0.1189 & 0.1189 & 0.1189 & 0.1189 & 0.1189 & 6 \\
\hline & B & 0.1432 & 0.1432 & 0.1432 & 0.1432 & 0.1432 & 0.1432 & 0.1432 & 5 \\
\hline & $\mathrm{C}$ & 0.1707 & 0.1707 & 0.1707 & 0.1707 & 0.1707 & 0.1707 & 0.1707 & 1 \\
\hline & $\mathrm{D}$ & 0.1640 & 0.1640 & 0.1640 & 0.1640 & 0.1640 & 0.1640 & 0.1640 & 3 \\
\hline & $\mathrm{E}$ & 0.1437 & 0.1437 & 0.1437 & 0.1437 & 0.1437 & 0.1437 & 0.1437 & 4 \\
\hline & $\mathrm{F}$ & 0.1646 & 0.1646 & 0.1646 & 0.1646 & 0.1646 & 0.1646 & 0.1646 & 2 \\
\hline & $\mathrm{G}$ & 0.0949 & 0.0949 & 0.0949 & 0.0949 & 0.0949 & 0.0949 & 0.0949 & 7 \\
\hline
\end{tabular}

The following top three factors were obtained.

(1) Factor C (0.1707): volume bought /sold by FIIs;

(2) Factor F (0.1646): trend forecast by FIIs;

(3) Factor D (0.1640): increase in the market trading volume.

Figure 4 summarizes the weights of influence for each factor.

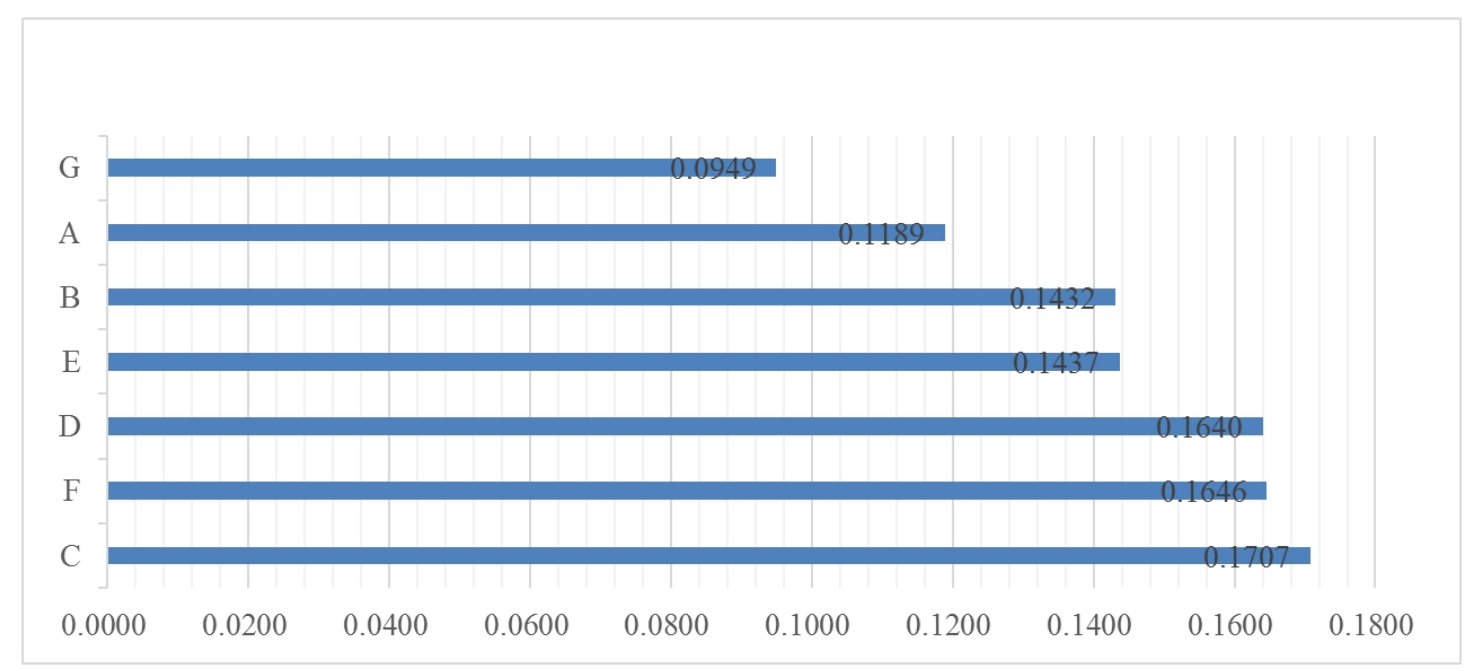

Figure 4. Wights of influence for each factor

Based on Table 11 and the prominence of factors, the factors with the top three DEMATEL ranks were identified as follows:

(1) Factor D (9.1489): increase in market trading volume;

(2) Factor C (9.1441): net volume bought/sold by FIIs; 
(3) Factor F (8.6633): trend forecast by FIIs.

Table 14 shows the overall ranking.

Table 14. Summary of overall ranking

\begin{tabular}{|c|c|c|c|c|}
\hline Factors & ANP Ranking & DEMATEL Ranking & Sum of Two Ranking & Overall Ranking \\
\hline A & 6 & 4 & 10 & $\mathbf{4}$ \\
\hline B & 5 & 5 & 10 & $\mathbf{4}$ \\
\hline C & 1 & 2 & 3 & $\mathbf{1}$ \\
\hline D & 3 & 1 & 4 & $\mathbf{2}$ \\
\hline E & 4 & 6 & 10 & $\mathbf{3}$ \\
\hline F & 2 & 3 & 14 & $\mathbf{7}$ \\
\hline G & 7 & 7 & & 5 \\
\hline
\end{tabular}

Table 14 shows that factor $\mathrm{C}$ is extremely important, factors $\mathrm{D}$ and $\mathrm{F}$ are very important, factors $\mathrm{A}, \mathrm{B}$, and $\mathrm{E}$ are moderately important, and factor $\mathrm{G}$ is the least important. Therefore, the key factors are $\mathrm{C}, \mathrm{D}$, and $\mathrm{F}$.

In this study, seven possible factors were considered for evaluating stock trading strategies and it was necessary to identify their determinants. Three factors were then selected based on integrated questionnaires completed by 12 financial experts, who had been trading stocks for more than three years. This complex management problem is a classic case of an MCDM, and the indicators had interdependent impacts.

\section{Step 7: Generating the causal diagram}

The causal diagram for the three key factors was generated as follows.

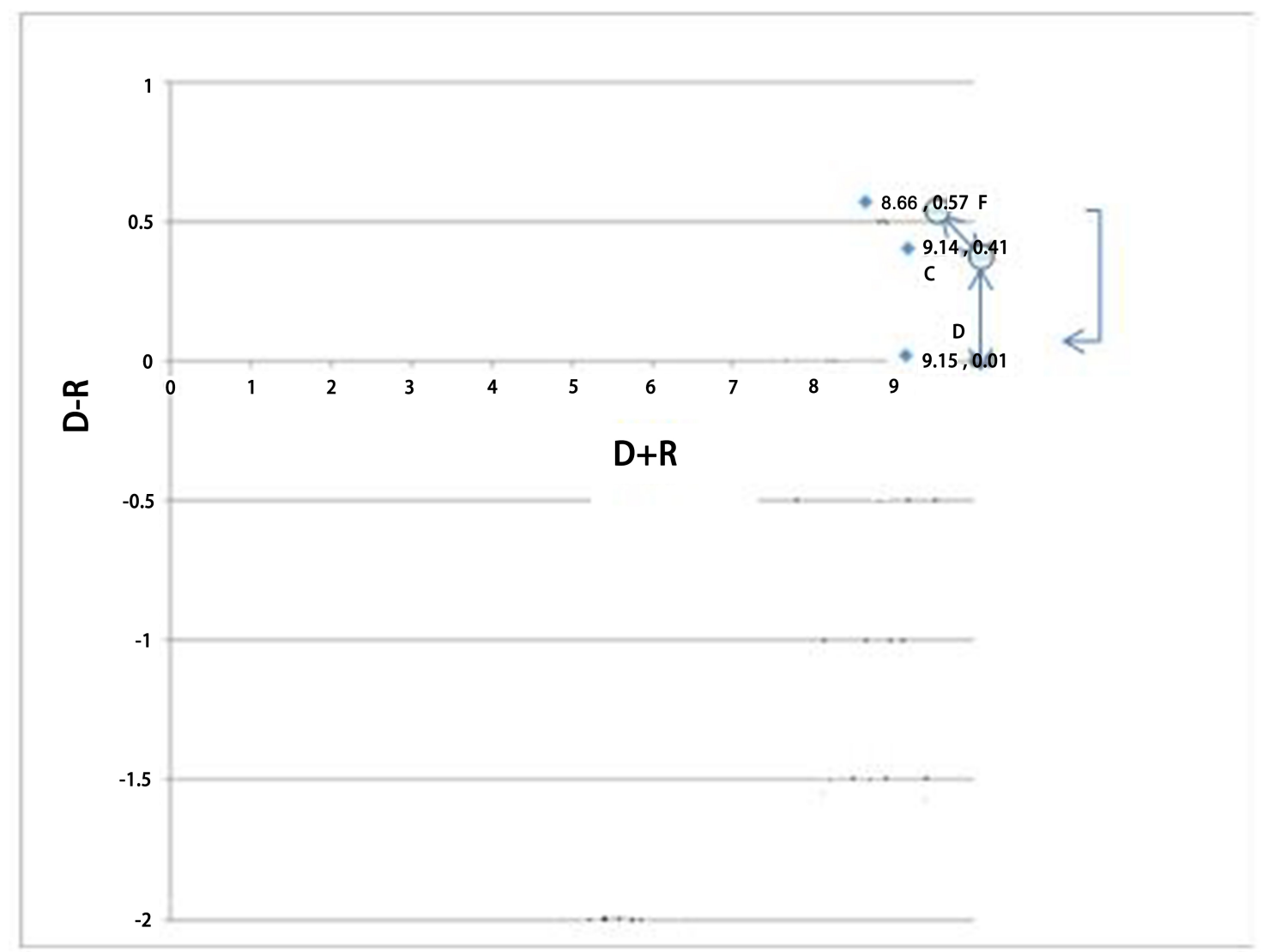

Notes: C indicates that the net volume bought/sold exceeding NT\$ 3.5 billion; D indicates that the market trading volume exceeds the 20-day average; $\mathrm{F}$ indicates that the open interest of foreign institutional investors exceeds 10,000 units.

Figure 5. Causal diagram for three key factors 


\section{Integrated Trading Strategy}

Strategies A and B were developed using Jesse L. Livermore's key price logic. However, Strategy C was developed using the D-ANP method with the top three key factors in Table 14. Strategy C did not incorporate Livermore's logic because the major variables in Livermore's logic (i.e., uptrend/downtrend) were not recognized as key factors by 12 financial experts. Ten pre-test transactions were conducted during the period from 2013 to 2014 (494 days) using all three strategies. If the WP of any strategy was below $50 \%$, then that strategy was abandoned. If the WP of any strategy was equal to or exceeded $50 \%$, then that strategy was considered to be effective, and it was used or amended for further testing based on data from the period from January 1, 2015 to June $30,2015$.

\section{Results of the pre-tests using Strategies A, B, and C}

This study only used 10 transactions initially because the process was very time consuming. In addition, if the WP was too low (i.e., below 50\%), this suggested that it was unnecessary for any reasonable trader to proceed, according to the Livermore's loss-cutting rule. However, if the strategy had a high WP, then this study extended the test period to 2 years (i.e., 24 transactions).

\section{WP is calculated as follows:}

$$
\mathrm{WP}=\frac{\text { The number of times of gaining profit }}{\text { total number of transactions }}
$$

Strategy A combines Livermore's uptrend/downtrend with the top financial condition for two consecutive days. The investor buys/sells TAIEX futures on the following day, and holds the position until the day when the closing price falls (rises) through the five-day MA line (10-day MA line), or the conditions are not fulfilled for two days continuously. The investor then closes out the transaction on the following day to stop loss/profit. A leverage of 10 times is used. WP was below 50\% (30\%), for Strategy A, so it was abandoned.

Table 15. Strategy A: Winning percentage in 10 pre-test transactions during 2013-2014

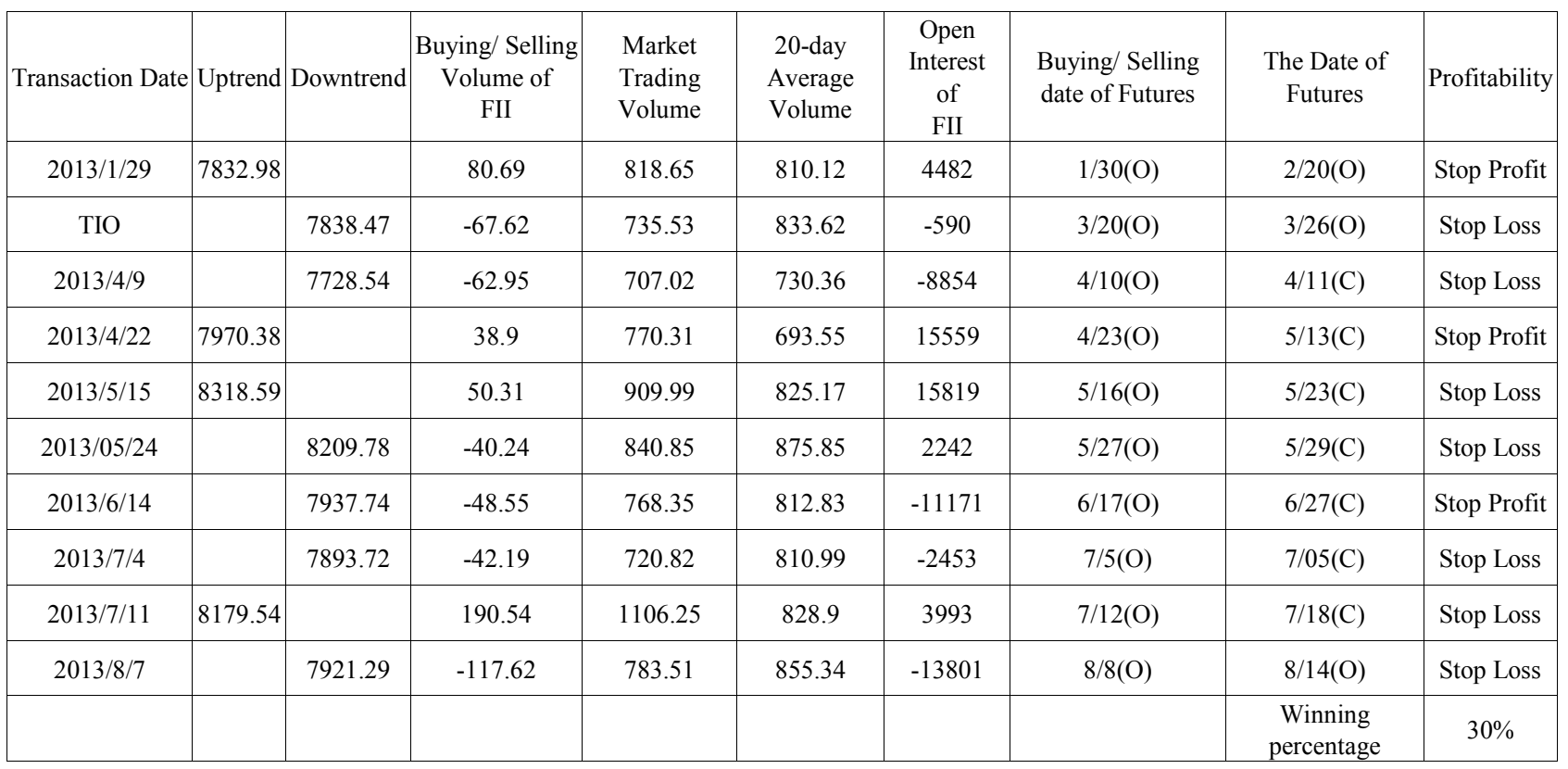

Notes: (1) Sources: BankTaiwan Securities;

(2) " $O$ ” denotes opening of market; " $C$ ” denotes closing of market; FII denotes foreign institutional investor.

Strategy B combines Livermore's uptrend/downtrend with the top three key financial factors $(\mathbf{C}, \mathbf{D}$, and $\mathbf{F})$. The investor buys/sells TAIEX futures on the following day, and holds the position until the day when the closing price falls/rises through the five-day MA line/10-day MA line to stop profit/loss. A leverage of $\mathbf{1 0}$ times is used.

WP was also too low (30\%), so Strategy B was abandoned. Thus, Strategies A and B are too far from the market trend. It was unnecessary to make any further amendments to strategies A and B based on Livermore's argument that a good trader should follow the general trend in the market. 
Table 16. Strategy B: Winning percentage in 10 pre-test transactions during 2013-2014

\begin{tabular}{|c|c|c|c|c|c|c|c|c|c|}
\hline Transaction Date & Uptrend & Downtrend & $\begin{array}{c}\text { Buying/Selling } \\
\text { Volume of } \\
\text { FII }\end{array}$ & $\begin{array}{l}\text { Market } \\
\text { Trading } \\
\text { Volume }\end{array}$ & $\begin{array}{l}20 \text {-day } \\
\text { Average } \\
\text { Volume }\end{array}$ & $\begin{array}{c}\text { Open } \\
\text { Interest } \\
\text { of } \\
\text { FII } \\
\end{array}$ & $\begin{array}{l}\text { Buying/Selling } \\
\text { Date of Futures }\end{array}$ & $\begin{array}{c}\text { The Closing } \\
\text { Transaction Date of } \\
\text { Futures }\end{array}$ & Profitability \\
\hline $2013 / 1 / 31$ & 7850.02 & & 54.14 & 809.17 & 797.63 & 7091 & $2 / 1(\mathrm{O})$ & $2 / 21(\mathrm{C})$ & Stop profit \\
\hline $2013 / 4 / 8$ & & 7752.79 & -54.55 & 911.5 & 742.39 & -9150 & $4 / 9(\mathrm{O})$ & 4/11(C) & Stop Loss \\
\hline $2013 / 4 / 19$ & 7930.8 & & 72.53 & 877.44 & 690.17 & 17959 & 4/22(O) & $5 / 13(\mathrm{C})$ & Stop profit \\
\hline $2013 / 5 / 15$ & 8318.59 & & 50.31 & 909.99 & 825.17 & 15819 & $5 / 16(\mathrm{O})$ & $5 / 23(\mathrm{C})$ & Stop Loss \\
\hline $2013 / 6 / 13$ & & 7951.66 & -171.19 & 899.71 & 835.68 & -11700 & $6 / 14(\mathrm{O})$ & 6/27(C) & Stop profit \\
\hline $2013 / 8 / 7$ & & 7921.29 & -72.65 & 783.51 & 855.34 & -13801 & $8 / 8(\mathrm{O})$ & $8 / 29(\mathrm{C})$ & Stop Loss \\
\hline 2013/9/10 & 8208.77 & & 120.85 & 894.38 & 795.59 & 5862 & 9/11(O) & 9/13(C) & Stop Loss \\
\hline $2013 / 10 / 3$ & 8359.02 & & 170.1 & 1157.99 & 798.74 & 10572 & $10 / 4(O)$ & $10 / 9(\mathrm{C})$ & Stop Loss \\
\hline $2013 / 10 / 31$ & 8450.06 & & 41.13 & 849.25 & 828.61 & 11173 & $11 / 1(\mathrm{O})$ & $11 / 1(\mathrm{C})$ & Stop Loss \\
\hline \multirow[t]{2}{*}{$2014 / 1 / 27$} & & 8462.57 & -171.9 & 1004.17 & 993.54 & -14158 & $2 / 5(\mathrm{O})$ & $2 / 12(\mathrm{C})$ & Stop Loss \\
\hline & & & & & & & & $\begin{array}{l}\text { Winning } \\
\text { Percentage }\end{array}$ & $30 \%$ \\
\hline
\end{tabular}

Notes: (1) Sources: Bank Taiwan Securities;

(2) " $O$ " denote opening of market; " $C$ " denotes closing of market; FII denotes foreign institutional investor.

Strategy $\mathbf{C}$ only uses the D-ANP method with the condition that the top key financial factor is satisfied for two continuous days, as well as either the second or the third key financial factor. The investor buys/sells TAIEX futures on the following day and holds the position until the closing TAIEX futures price falls/rises through the five-day MA line/10-day MA line. The investor then closes out the transactions to stop loss/profit. A leverage of 10 times is used.

WP exceeded 50\% (60\%) for Strategy C, so it was retained for future improvement.

Table 17. Strategy C: Winning percentage in 10 pre-test transactions during 2013-2014

\begin{tabular}{|c|c|c|c|c|c|c|c|c|c|}
\hline $\begin{array}{c}\text { Transaction } \\
\text { Date }\end{array}$ & Uptrend & Downtrend & $\begin{array}{c}\text { Buying/Selling } \\
\text { Volume of } \\
\text { FII }\end{array}$ & $\begin{array}{l}\text { Market } \\
\text { Trading } \\
\text { Volume }\end{array}$ & $\begin{array}{l}\text { 20-day } \\
\text { average } \\
\text { Volume }\end{array}$ & $\begin{array}{c}\text { Open } \\
\text { Interest } \\
\text { of } \\
\text { FII } \\
\end{array}$ & $\begin{array}{c}\text { Buying/Selling } \\
\text { Date of } \\
\text { Futures }\end{array}$ & $\begin{array}{c}\text { The Closing } \\
\text { Transaction } \\
\text { Date of } \\
\text { Futures } \\
\end{array}$ & Profitability \\
\hline $2013 / 1 / 29$ & 7802 & & 76.07 & 763.33 & 808.68 & 6555 & $1 / 30(\mathrm{O})$ & $2 / 21(\mathrm{C})$ & Stop Profit \\
\hline $2013 / 4 / 9$ & & 7728.54 & -62.95 & 707.02 & 730.36 & -8854 & $4 / 10(\mathrm{O})$ & $4 / 11(\mathrm{C})$ & Stop Loss \\
\hline $2013 / 4 / 22$ & 7970.38 & & 38.9 & 770.31 & 693.55 & 15559 & $4 / 23(\mathrm{O})$ & $5 / 13(\mathrm{C})$ & Stop Profit \\
\hline $2013 / 5 / 15$ & 8318.59 & & 50.31 & 909.99 & 825.17 & 15819 & $5 / 16(\mathrm{O})$ & $5 / 23(\mathrm{C})$ & Stop Loss \\
\hline $2013 / 5 / 31$ & & 8254.8 & -63.23 & 1136.74 & 855.16 & -1461 & 6/03(O) & $6 / 27(\mathrm{C})$ & Stop Profit \\
\hline $2013 / 7 / 3$ & & 7911.42 & -48.49 & 864.28 & 813.9 & -2532 & $7 / 04(\mathrm{O})$ & $7 / 05(\mathrm{C})$ & Stop Loss \\
\hline $2013 / 7 / 10$ & 8011.69 & & 60.08 & 871.05 & 818.57 & 4492 & $7 / 11(\mathrm{O})$ & $7 / 18(\mathrm{C})$ & Stop Profit \\
\hline $2013 / 8 / 6$ & & 8038.91 & -88.72 & 836.09 & 859.71 & -12602 & $8 / 07(\mathrm{O})$ & $8 / 29(\mathrm{C})$ & Stop Profit \\
\hline $2013 / 8 / 30$ & 8021.89 & & 55.74 & 822.09 & 772.48 & -7 & $9 / 02(\mathrm{O})$ & $9 / 13(\mathrm{C})$ & Stop Profit \\
\hline \multirow[t]{2}{*}{$2013 / 9 / 24$} & 8299.12 & & 56.82 & 816.77 & 778.57 & 4448 & $9 / 25(\mathrm{O})$ & $9 / 26(\mathrm{C})$ & Stop Loss \\
\hline & & & & & & & & $\begin{array}{c}\text { Winning } \\
\text { percentage }\end{array}$ & $60 \%$ \\
\hline
\end{tabular}

Notes: (1) Sources: Bank Taiwan Securities;

(2) "O" denotes opening of market; " $C$ " denotes closing of market; FII denotes the foreign institutional investor. 
The "uptrend/downtrend" used in Livermore's logic is different from the "uptrend/downtrend" mentioned in Strategy $\mathrm{C}$ for the following reasons.

Jesse's uptrend (downtrend) is defined as a stock reaching a new high (low) in its movement after making a normal reaction (rally), thereby implying that, if one has a stock in an uptrend (a downtrend) that has just reached a new high (low) and then drops back (moves forward) in a normal manner, then when it starts moving up (down) again and exceeds the previous high (low), one should buy (sell) it.

However, the uptrend/downtrend mentioned in Strategy C is defined with the common meaning: prices keep reaching greater highs and greater lows, whereas a downtrend is characterized by lower lows and lower highs.

This study first determined the relationship for each item in Strategy C, before exploring why some transactions failed, and we then made some adjustments. The pre-test results for Strategy $\mathrm{C}$ showed that this strategy has the following problems.

(1) If prices are following an uptrend and the conditions for Strategy $\mathrm{C}$ are satisfied, then the investor closes out the transaction to stop loss/profit, and then re-enters the market by buying the TAIEX futures according to Strategy C. However, this decision is very risky because the investor may be forced to stop loss if the uptrend in the TAIEX reverses.

(2) When the TAIEX exceeds 9,000 points, and the extent of its fluctuations increases, then if the closing index departs from the uptrend with a strong downward reversal, and falls through the five-day MA line, the investor will be forced to stop profit/loss.

(3) When the natural reversal of the uptrend fulfills the requirements for Strategy $\mathrm{C}$, the investor will erroneously identify the beginning of a downtrend, and stop profit/loss immediately.

(4) When the downtrend required by Strategy C fails, the stop loss point may be too low, and thus a downtrend normally causes an investor to sell positions heavily. Thus, the TAIEX futures may decline readily and dramatically through the stop loss point.

(5) When the five-day, 10-day, 20-day, and 60-day MA lines are interconnected in a complex manner, and the future trend is not obvious, but the requirements for Strategy C are fulfilled, then the investor will enter the market, but they will be forced to stop loss later.

(6) A downtrend in TAIEX usually causes FIIs to sell TAIEX futures heavily, so the net selling volume may exceed NT\$ 8 billion. However, when the market meets the conditions for Strategy $\mathrm{C}$, the TAIEX will have already fallen considerably; thus, FII will push the price up, and resell their positions.

(7) The TAIEX can fall quickly during a gap in the trading session, but the investor cannot implement Strategy $\mathrm{C}$ until the futures market closes that day and the investor can record their financial data. Thus, the investor subsequently re-enters the market when it opens the following day and they have missed the opportunity.

(8) When the downtrend of TAIEX satisfies the requirements for Strategy C, the investor closes out the transaction to stop loss. The investor then re-enters the market to sell their position. If the stock market exhibits a $\mathrm{W}$ formation, then the investor must stop loss when the TAIEX rallies.

Based on the problems described above, some adjustments were made to Strategy $\mathrm{C}$ as follows:

(1) After the uptrend ends, the TAIEX declines through the five-day MA line, and the investor closes out the transaction to stop profit. Thus, if the uptrend satisfies the conditions for Strategy $\mathrm{C}$ again, then the investor does not have to re-enter the market until the uptrend ends.

(2) The stop loss on TAIEX futures must be extended after the barrier of 9,000 points is reached, so the original requirement for a decline through the five-day MA line was changed into a requirement for a decline through the 10-day MA line for stopping profit/loss.

(3) When the requirement for Strategy $\mathrm{C}$ is satisfied during the natural reversal of an uptrend, the investor should not implement Strategy C.

(4) When a downtrend in the TAIEX satisfies the conditions for Strategy C, and the TAIEX rises to the 10-day MA line, then the investor re-enters the market and immediately sells TAIEX futures.

(5) During a downtrend in the TAIEX, when the TAIEX is above the 10-day MA line, the investor should not implement Strategy $\mathrm{C}$ because the future trend in the TAIEX is not obvious.

(6) During a downtrend in the TAIEX, if the net volume sold by FII exceeds NT\$8 billion during one day rather than two days, as in the previous condition, then the requirement in Strategy $C$ is satisfied.

(7) During a dramatic downtrend in the TAIEX, the investor should promptly short the TAIEX futures position, to ensure that no opportunity of stopping loss is missed.

(8) At the end of a downtrend in the TAIEX that breaks the 10-day MA line, the investor closes out the transaction to stop profit. Subsequently, the investor re-enters the market based on whether the opening interest of the FII exceeds 20,000 units.

This study summarizes the eight amended items in Strategy C in Table 18. 
Table 18. Eight amendments to strategy $\mathrm{C}$

\begin{tabular}{|c|c|c|}
\hline Amended Item & Reason & Amendment \\
\hline Uptrend & $\begin{array}{l}\text { Re-entering the market after the uptrend ends seems too } \\
\text { risky. }\end{array}$ & $\begin{array}{l}\text { If the investor closes out the transaction, he/she should not } \\
\text { re-enter the market. }\end{array}$ \\
\hline Uptrend & $\begin{array}{l}\text { When the TAIEX exceeds } 9,000 \text { points in an uptrend and } \\
\text { falls back through the five-day MA Line, the investor stops } \\
\text { profit too early. }\end{array}$ & $\begin{array}{l}\text { If the TAIEX breaks the barrier of } 9,000 \text { points, then the } \\
\text { five-day MA-line requirement for stopping profit should be } \\
\text { changed to the 10-day MA-line condition. }\end{array}$ \\
\hline Natural reversal & $\begin{array}{l}\text { The natural reversal of an uptrend is misidentified as the } \\
\text { start of a downtrend. }\end{array}$ & $\begin{array}{l}\text { Do not execute Strategy } \mathrm{C} \text { when the TAIEX reaches the } \\
\text { natural reversal region. }\end{array}$ \\
\hline Downtrend & $\begin{array}{c}\text { The five-day MA Line is too low for stop loss during a } \\
\text { downtrend. }\end{array}$ & $\begin{array}{l}\text { The five-day MA line is changed to the 10-day MA line for } \\
\text { stopping loss. }\end{array}$ \\
\hline Downtrend & $\begin{array}{l}\text { When the different-day MA lines are interwined and } \\
\text { downtrend is not obvious, an investor may easily suffer a } \\
\text { loss by re-entering the market too early. }\end{array}$ & $\begin{array}{l}\text { Do not implement Strategy C if the TAIEX exceeds the } \\
\text { 10-day MA line. }\end{array}$ \\
\hline Downtrend & $\begin{array}{l}\text { The opportunity to close out a transaction during a } \\
\text { downtrend is easily missed. }\end{array}$ & $\begin{array}{l}\text { If the net selling volume exceeds NT\$ } 8 \text { billion during the } \\
\text { downtrend, then Strategy C should be executed. }\end{array}$ \\
\hline Downtrend & $\begin{array}{l}\text { Since the TAIEX falls very quickly, and has a gap in the } \\
\text { decline, the investor cannot implement Strategy C until the } \\
\text { futures market closes that day, so the opportunity of } \\
\text { stopping loss is missed. }\end{array}$ & $\begin{array}{l}\text { The investor shorts the TAIEX futures position during the } \\
\text { trading session, and only later analyzes the related financial } \\
\text { data. }\end{array}$ \\
\hline Downtrend & $\begin{array}{l}\text { The risk is very high if the investor re-enters the market } \\
\text { immediately after a downtrend ends. }\end{array}$ & $\begin{array}{l}\text { The investor re-enters the market when the opening interest } \\
\text { of the FII exceeds } 20,000 \text { units. }\end{array}$ \\
\hline
\end{tabular}

Tables 19 and 20 show the results obtained after implementing the amended Strategy C.

Table 19. Winning percentage of the amended Strategy C during 2013- 2014

\begin{tabular}{|c|c|c|c|c|c|c|c|c|c|}
\hline Dates & Uptrend & Downtrend & $\begin{array}{c}\text { Buying/Selling } \\
\text { Vol. of FII }\end{array}$ & $\begin{array}{l}\text { Market } \\
\text { Trading } \\
\text { Volume }\end{array}$ & $\begin{array}{c}\text { 20-day } \\
\text { average } \\
\text { Volume }\end{array}$ & $\begin{array}{c}\text { Open } \\
\text { Interest of } \\
\text { FII }\end{array}$ & $\begin{array}{c}\text { Buying/Selling } \\
\text { Date of } \\
\text { Futures }\end{array}$ & $\begin{array}{c}\text { Closing } \\
\text { Transaction } \\
\text { Date of } \\
\text { Futures } \\
\end{array}$ & Profitability \\
\hline $2013 / 1 / 16$ & & 7700.43 & -41.66 & 842.99 & 790.99 & -204 & $1 / 17(\mathrm{O})$ & $1 / 22(\mathrm{C})$ & Stop Loss \\
\hline 2013/1/29 & 7802 & & 76.07 & 763.33 & 808.68 & 6555 & $1 / 30(\mathrm{O})$ & $2 / 21(\mathrm{C})$ & Stop Profit \\
\hline $2013 / 4 / 9$ & & 7728.54 & -62.95 & 707.02 & 730.36 & -8854 & $4 / 11(\mathrm{O})$ & $4 / 19(O)$ & Stop Loss \\
\hline $2013 / 4 / 22$ & 7970.38 & & 38.9 & 770.31 & 693.55 & 15559 & $4 / 23(\mathrm{O})$ & $5 / 13(\mathrm{C})$ & Stop Profit \\
\hline $2013 / 5 / 31$ & & 8254.8 & -63.23 & 1136.74 & 855.16 & -1461 & $6 / 3(\mathrm{O})$ & $6 / 27(\mathrm{C})$ & Stop Profit \\
\hline \begin{tabular}{|l|}
$2013 / 7 / 10$ \\
\end{tabular} & 8011.69 & & 60.08 & 871.05 & 818.57 & 4492 & $7 / 11(\mathrm{O})$ & $7 / 18(\mathrm{C})$ & Stop Profit \\
\hline $2013 / 8 / 6$ & & 8038.91 & -88.72 & 836.09 & 859.71 & -12602 & $8 / 7(\mathrm{O})$ & $8 / 29(\mathrm{C})$ & Stop Profit \\
\hline 2013/8/30 & 8021.89 & & 55.74 & 822.09 & 772.48 & -7 & $9 / 2(\mathrm{O})$ & 9/13(C) & Stop Profit \\
\hline $2013 / 11 / 14$ & & 8134.91 & -59.31 & 746.14 & 769.05 & -16639 & $11 / 18(\mathrm{O})$ & $11 / 19(\mathrm{O})$ & Stop Loss \\
\hline $2013 / 11 / 29$ & 8406.83 & & 70.29 & 857.98 & 763.61 & 7639 & $12 / 02(\mathrm{O})$ & $12 / 5(\mathrm{C})$ & Stop Loss \\
\hline $2014 / 1 / 16$ & 8612.11 & & 108.67 & 1091.94 & 902.17 & -10308 & $1 / 17(\mathrm{O})$ & $1 / 21(\mathrm{C})$ & Stop Profit \\
\hline $2014 / 1 / 27$ & & 8462.57 & -171.9 & 1004.17 & 993.54 & -14158 & $1 / 27(C)$ & $2 / 6(\mathrm{C})$ & Stop Profit \\
\hline $2014 / 3 / 26$ & 8737.27 & & 58.95 & 936.6 & 978.9 & 12067 & $3 / 27(\mathrm{O})$ & 4/7(C) & Stop Profit \\
\hline $2014 / 5 / 14$ & 8875.16 & & 76.89 & 873.79 & 954 & 21261 & $5 / 15(\mathrm{O})$ & $6 / 23(\mathrm{C})$ & Stop Profit \\
\hline $2014 / 5 / 23$ & 9008.22 & & 35.7 & 974.45 & 923.1 & 28689 & $5 / 26(\mathrm{O})$ & 6/23(C) & Stop Profit \\
\hline $2014 / 7 / 1$ & 9441.92 & & 52.48 & 1154.73 & 1027.9 & 10719 & $7 / 2(\mathrm{O})$ & 7/16(C) & Stop Profit \\
\hline $2014 / 7 / 31$ & & 9315.85 & -104.16 & 1066.16 & 1142.49 & -7020 & $8 / 4(\mathrm{C})$ & 8/13(C) & Stop Profit \\
\hline $2014 / 8 / 20$ & 9288.05 & & 56.73 & 908.79 & 977.61 & -3235 & $8 / 21(\mathrm{O})$ & $9 / 2(\mathrm{C})$ & Stop Profit \\
\hline $2014 / 9 / 10$ & & 9357.61 & -104.09 & 787.31 & 875.52 & -16138 & 9/11(O) & 10/3(C) & Stop Profit \\
\hline $2014 / 10 / 8$ & & 8955.18 & -46.09 & 744.08 & 799.8 & -25670 & $10 / 9(\mathrm{O})$ & $10 / 22(\mathrm{C})$ & Stop Profit \\
\hline $2014 / 10 / 28$ & 8773.55 & & 122.39 & 859.14 & 840.96 & -3384 & $10 / 29(\mathrm{O})$ & $11 / 5(\mathrm{C})$ & Stop Profit \\
\hline $2014 / 11 / 20$ & 9078.87 & & 99.8 & 924.23 & 795.51 & 13035 & $11 / 21(\mathrm{O})$ & $12 / 1(\mathrm{O})$ & Stop Loss \\
\hline $2014 / 12 / 10$ & & 9032.16 & -6706 & 926.1 & 870.95 & -6706 & $12 / 11(\mathrm{O})$ & $12 / 22(\mathrm{O})$ & Stop Loss \\
\hline \multirow[t]{2}{*}{ 2014/12/22 } & 9095 & & 42.06 & 810.25 & 907.77 & 10107 & $12 / 23(\mathrm{O})$ & $1 / 5(\mathrm{C})$ & Stop Profit \\
\hline & & & & $\begin{array}{c}\text { Total } \\
\text { Transaction }\end{array}$ & 24 & $\begin{array}{c}\text { Time of stop } \\
\text { profit }\end{array}$ & 18 & $\begin{array}{l}\text { Winning } \\
\text { percentage }\end{array}$ & $75 \%$ \\
\hline
\end{tabular}

Notes: (1) Sources: Bank Taiwan Securities;

(2) "O" denotes opening of market; " $C$ " denotes closing of market; FII denotes foreign institutional investor. 
Table 20 summarizes the profit in points gained in each trade, whether the trade stops profit or loss, and the accumulated net profits during 2013- 2014.

Table 20. Profit in points gained using amended Strategy C during 2013- 2014

\begin{tabular}{|c|c|c|c|c|c|c|c|c|}
\hline Date & Uptrend & Downtrend & $\begin{array}{c}\text { Initial } \\
\text { Buying/Selling } \\
\text { Date }\end{array}$ & $\begin{array}{c}\text { The Closing } \\
\text { Transaction } \\
\text { Date of } \\
\text { Futures } \\
\end{array}$ & $\begin{array}{c}\text { Points of Initial } \\
\text { Buying/Selling }\end{array}$ & $\begin{array}{c}\text { Points of } \\
\text { Closing } \\
\text { Transaction }\end{array}$ & Profitability & Net Profit \\
\hline $2013 / 1 / 16$ & & 7700.43 & $1 / 17(\mathrm{O})$ & $1 / 22(\mathrm{C})$ & 7702 & 7748 & Stop Loss & (46) \\
\hline $2013 / 1 / 29$ & 7802 & & $1 / 30(\mathrm{O})$ & $2 / 21(\mathrm{C})$ & 7846 & 7949 & Stop Profit & 103 \\
\hline $2013 / 4 / 9$ & & 7728.54 & $4 / 11(\mathrm{O})$ & 4/19(O) & 7776 & 7784 & Stop Loss & $(8)$ \\
\hline $2013 / 4 / 22$ & 7970.38 & & $4 / 23(\mathrm{O})$ & 5/13(C) & 7942 & 8260 & Stop Profit & 318 \\
\hline $2013 / 5 / 31$ & & 8254.8 & $6 / 3(\mathrm{O})$ & $6 / 27(\mathrm{C})$ & 8100 & 7715 & Stop Profit & 385 \\
\hline $2013 / 7 / 10$ & 8011.69 & & $7 / 11(\mathrm{O})$ & 7/18(C) & 8107 & 8100 & Stop Loss & $(7)$ \\
\hline $2013 / 8 / 6$ & & 8038.91 & $8 / 7(\mathrm{O})$ & $8 / 29(\mathrm{C})$ & 7912 & 7894 & Stop Profit & 18 \\
\hline $2013 / 8 / 30$ & 8021.89 & & $9 / 2(\mathrm{O})$ & 9/13(C) & 7964 & 8147 & Stop Profit & 183 \\
\hline $2013 / 11 / 14$ & & 8134.91 & $11 / 18(\mathrm{O})$ & $11 / 19(\mathrm{O})$ & 8194 & 8224 & Stop Loss & $(30)$ \\
\hline $2013 / 11 / 29$ & 8406.83 & & $12 / 02(\mathrm{O})$ & $12 / 5(\mathrm{C})$ & 8431 & 8378 & Stop Loss & $(53)$ \\
\hline $2014 / 1 / 16$ & 8612.11 & & $1 / 17(\mathrm{O})$ & $1 / 21(\mathrm{C})$ & 8610 & 8621 & Stop Profit & 11 \\
\hline $2014 / 1 / 27$ & & 8462.57 & $1 / 27(\mathrm{C})$ & $2 / 6(\mathrm{C})$ & 8449 & 8276 & Stop Profit & 173 \\
\hline $2014 / 3 / 26$ & 8737.27 & & $3 / 27(\mathrm{O})$ & $4 / 7(\mathrm{C})$ & 8705 & 8858 & Stop Profit & 153 \\
\hline $2014 / 5 / 14$ & 8875.16 & & $5 / 15(\mathrm{O})$ & 6/23(C) & 8868 & 9167 & Stop Profit & 299 \\
\hline $2014 / 5 / 23$ & 9008.22 & & $5 / 26(\mathrm{O})$ & 6/23(C) & 9020 & 9167 & Stop Profit & 147 \\
\hline $2014 / 7 / 1$ & 9441.92 & & $7 / 2(\mathrm{O})$ & $7 / 16(C)$ & 9404 & 9483 & Stop Profit & 79 \\
\hline $2014 / 7 / 31$ & & 9315.85 & $8 / 4(C)$ & $8 / 13(\mathrm{C})$ & 9285 & 9199 & Stop Profit & 86 \\
\hline $2014 / 8 / 20$ & 9288.05 & & $8 / 21(\mathrm{O})$ & $9 / 2(C)$ & 9260 & 9409 & Stop Profit & 149 \\
\hline $2014 / 9 / 10$ & & 9357.61 & $9 / 11(\mathrm{O})$ & $10 / 3(\mathrm{C})$ & 9376 & 9098 & Stop Profit & 278 \\
\hline $2014 / 10 / 8$ & & 8955.18 & $10 / 9(\mathrm{O})$ & $10 / 22(\mathrm{C})$ & 8997 & 8744 & Stop Profit & 253 \\
\hline $2014 / 10 / 28$ & 8773.55 & & $10 / 29(\mathrm{O})$ & $11 / 5(\mathrm{C})$ & 8833 & 8985 & Stop Profit & 152 \\
\hline $2014 / 11 / 20$ & 9078.87 & & $11 / 21(\mathrm{O})$ & $12 / 1(\mathrm{O})$ & 9119 & 9036 & Stop Loss & (83) \\
\hline $2014 / 12 / 10$ & & 9032.16 & 12/11(O) & $12 / 22(\mathrm{O})$ & 8976 & 9031 & Stop Loss & $(55)$ \\
\hline $2014 / 12 / 22$ & 9095 & & $12 / 23(\mathrm{O})$ & $1 / 5(\mathrm{C})$ & 9134 & 9250 & Stop Profit & 116 \\
\hline & & $2013 / 1 / 2$ & $\begin{array}{c}\text { Opening points of } \\
\text { futures }\end{array}$ & 7720 & \multicolumn{3}{|c|}{ Total profit points of the amended Strategy C } & 2621 \\
\hline & & $2014 / 12 / 31$ & $\begin{array}{l}\text { Closing point of } \\
\text { futures }\end{array}$ & 9281 & \multicolumn{3}{|c|}{ Points difference of TAIEX futures } & 1561 \\
\hline & & & & & \multicolumn{3}{|c|}{ Accumulated net profit points } & 1060 \\
\hline
\end{tabular}

Notes: (1) Sources: Bank Taiwan Securities;

(2) "O" denotes opening of market; " $C$ " denotes closing of market;

According to Table 20, a total of 24 transactions occurred from 2013 to 2014. Each transaction cost $\$ 300$, so the total transaction cost over the two years was:

$$
\text { NT\$300 x } 24=\text { NT\$7,200. }
$$

The accumulated net profit during 2013 to 2014 was 2,621 points, so the total profit over the two years was:

$$
\text { NT\$200 x 2,621 = NT\$542,000. }
$$

The net profit over the two years was,

$$
\text { NT\$524,200 - NT\$7,200 = NT\$517,000. }
$$

Therefore, the accumulated rate of return using amended Strategy $\mathrm{C}$ in the two years was:

$$
\text { NT\$517,000/ NT } \$ 170,000=304.1 \% \text {. }
$$

The annualized rate of return for the amended Strategy C during 2013- 2014 was:

$$
\sqrt{1+3.041}-1=101.0 \%
$$

However, the rate of return on TAIEX futures during the period of 2013-2014 was:

$$
(200 \times 1,561=312,000) / 170,000=83.6 \% .
$$

Thus, the annualized rate of return on TAIEX futures was:

$$
\sqrt{(1+0.836)}-1=35.5 \% \text {. }
$$

In summary, the net profit from the amended Strategy C during 2013- 2014 was $\$ 517,000$, and the annualized rate of return was $101.0 \%$. This result demonstrates that the amended Strategy C outperformed TAIEX futures $(\$ 312,200)$ and annualized ROR (35.5\%) during the period from 2013 to 2014. The results in Table 21 illustrate the performance of the amended Strategy C from January 1, 2015 to June 30, 2015. 
Table 21. Winning percentage of amended Strategy C during 2015/01/01 2015/06/30

\begin{tabular}{|c|c|c|c|c|c|c|c|c|c|}
\hline Dates & Uptrend & Downtrend & $\begin{array}{l}\text { Net Buying/ } \\
\text { Selling of FII }\end{array}$ & $\begin{array}{l}\text { Market } \\
\text { Trading } \\
\text { Volume } \\
\end{array}$ & $\begin{array}{l}\text { Ave. 20-day } \\
\text { Volume }\end{array}$ & $\begin{array}{c}\text { Open Interest } \\
\text { of FII }\end{array}$ & $\begin{array}{c}\text { Buying/Selling } \\
\text { Date of first } \\
\text { Transaction } \\
\end{array}$ & $\begin{array}{c}\text { Closing } \\
\text { Transaction } \\
\text { Date } \\
\end{array}$ & Profitability \\
\hline $2015 / 1 / 21$ & 9251.69 & & 85.66 & 870.22 & 835.82 & 15020 & $1 / 21(\mathrm{O})$ & 1/29(C) & Stop Profit \\
\hline $2015 / 2 / 11$ & 9462.22 & & 74.7 & 974.22 & 886.80 & 12482 & 2/12(O) & $3 / 2(\mathrm{C})$ & Stop Profit \\
\hline $2015 / 3 / 19$ & 9736.73 & & 86.93 & 1182.44 & 939.35 & 17626 & $3 / 20(\mathrm{O})$ & $3 / 25(\mathrm{C})$ & Stop Loss \\
\hline $2015 / 4 / 15$ & & $9,540.06$ & -216.24 & 1144.65 & 1019.37 & -4088 & 4/16(O) & 4/16(C) & Stop Loss \\
\hline $2015 / 4 / 23$ & 9797.49 & & 223.77 & 1445.26 & 1014.44 & 11460 & 4/23(C) & 4/29(C) & Stop Profit \\
\hline $2015 / 5 / 19$ & 9716.77 & & 97.83 & 1084.89 & 1063.47 & -12850 & $5 / 20(\mathrm{O})$ & $5 / 21(\mathrm{O})$ & Stop Loss \\
\hline \multirow[t]{2}{*}{$2015 / 6 / 1$} & & 9625.69 & -91.28 & 923.38 & 971.3 & -10907 & $6 / 2(\mathrm{O})$ & 6/22(C) & Stop Profit \\
\hline & & & & $\begin{array}{c}\text { Total } \\
\text { transaction }\end{array}$ & 7 & $\begin{array}{l}\text { Stop profit } \\
\text { Times }\end{array}$ & 4 & $\begin{array}{c}\text { Winning } \\
\text { percentage }\end{array}$ & $57 \%$ \\
\hline
\end{tabular}

Notes: (1) Sources: Bank Taiwan Securities;

(2) $O$ denotes opening of market; $C$ denotes closing of market;

Table 22. Profit in points gained using amended Strategy C during 2015/01/01-2015/06/30

\begin{tabular}{|c|c|c|c|c|c|c|c|c|}
\hline Dates & Uptrend & Downtrend & $\begin{array}{c}\text { Buying/Selling Date of the } \\
\mathbf{1}^{\text {st }} \text { Transaction }\end{array}$ & $\begin{array}{c}\text { Closing } \\
\text { Transaction } \\
\text { Date }\end{array}$ & $\begin{array}{c}\text { Buying/Selling Point } \\
\text { of the 1 } \\
\text { Transaction }\end{array}$ & $\begin{array}{c}\text { Closing } \\
\text { Transaction } \\
\text { Point }\end{array}$ & Profitability & $\begin{array}{c}\text { Points } \\
\text { Difference }\end{array}$ \\
\hline $2015 / 1 / 21$ & 9251.69 & & $1 / 21(\mathrm{O})$ & $1 / 29(\mathrm{C})$ & & 9428 & Stop Profit & 146 \\
\hline $2015 / 2 / 11$ & 9462.22 & & $2 / 12(\mathrm{O})$ & $3 / 2(\mathrm{C})$ & 9499 & 9631 & Stop Profit & 132 \\
\hline $2015 / 3 / 19$ & 9736.73 & & $3 / 20(\mathrm{O})$ & $3 / 25(\mathrm{C})$ & 9742 & 9688 & Stop Loss & $(54)$ \\
\hline $2015 / 4 / 15$ & & 9540.06 & $4 / 16(\mathrm{O})$ & $4 / 16(\mathrm{C})$ & 9561 & 9644 & Stop Loss & $(83)$ \\
\hline $2015 / 4 / 23$ & 9797.49 & & $4 / 23(\mathrm{C})$ & $4 / 29(\mathrm{C})$ & 9838 & 9907 & Stop Profit & 69 \\
\hline $2015 / 5 / 19$ & 9716.77 & & $5 / 20(\mathrm{O})$ & $5 / 21(\mathrm{C})$ & 9704 & 9541 & Stop Loss & $(163)$ \\
\hline $2015 / 6 / 1$ & & 9625.69 & $6 / 2(\mathrm{O})$ & $6 / 22(\mathrm{C})$ & 9586 & 9178 & Stop Profit & 408 \\
\hline & & $2015 / 1 / 5$ & $\begin{array}{c}\text { Opening point of TAIEX } \\
\text { futures }\end{array}$ & 9238 & Profit points for the Amended Strategy C & 455 \\
\hline & & $2015 / 6 / 30$ & $\begin{array}{c}\text { Closing point of TAIEX } \\
\text { Futures }\end{array}$ & 9211 & \multicolumn{2}{|c|}{ Profit points for TAIEX Futures } & $(27)$ \\
\hline
\end{tabular}

Notes: (1) Sources: Bank Taiwan Securities;

(2) $O$ denotes opening of the market and $C$ denotes closing of the market;

Table 22 summarizes the net profit/loss in each transaction. Seven transactions were conducted during the period from $2015 / 01 / 01$ to $2015 / 06 / 30$. Each transaction cost was $\$ 300$ and the cost of seven transactions was:

$$
\text { NT } \$ 300 \times 7=\text { NT\$ } 2,100 .
$$

Since the accumulated profit in points that is gained by amended Strategy C during the period from January 1, 2015 to June 30,2015 is 455 , the profit is calculated as follows.

$$
\text { NT } \$ 200 \times 455=\text { NT\$ } 91,000 \text {. }
$$

Therefore, the net profit from amended Strategy $\mathrm{C}$ during the period from January 1, 2015 to June 30, 2015 was:

$$
\text { NT\$ } \$ 1,000-\mathrm{NT} \$ 2,100=\mathrm{NT} \$ 88,900 \text {. }
$$

The rate of return from amended Strategy $\mathrm{C}$ during the period from January 1, 2015 to June 30, 2015 was:

$$
\text { NT } \$ 88,900 / \text { NT } \$ 170,000=52.3 \% \text {. }
$$

Accordingly, the annualized rate of return from amended
Strategy C during the period from January 1, 2015 to June 10, 2015 was:

$$
(1+0.529)^{2}-1=133.8 \% .
$$

However, the rate of return on TAIEX futures during the period from January 1, 2015 to June 30, 2015 was:

$$
(\mathrm{NT} \$ 200 \times 27=\mathrm{NT} \$ 5,400) / \mathrm{NT} \$ 170,000=3.2 \% \text {. }
$$

Therefore, the annualized rate of return from TAIEX futures during the period from January 1, 2015 to June 30, 2015 was:

$$
(1+0.032)^{2}-1=6.5 \% .
$$

In summary, the empirical results demonstrate that during the period from January 1, 2015 to June 30, 2015, the amended Strategy C yielded positive returns of NT $\$ 70,000$, and the annualized rate of return was $133.8 \%$. However, the positive return from TAIEX futures during the period from January 1, 2015 to June 30, 2015 was NT\$ 5,400, and the 
annualized rate of return was $6.5 \%$. These results show that the amended Strategy $\mathrm{C}$ also performed better than TAIEX futures in the period from January 1, 2015 to June 30, 2015.

\section{Conclusions}

In this study, the suggestions of 12 financial experts elicited using questionnaires were used to identify three key factors that affect Taiwanese stocks and futures markets. These three key factors comprised "net volume bought/sold by FIIs" "total trading volume", and "trends predicted by FIIs" These three key factors were then integrated into Livermore's key price logic to obtain Strategies A and B. By contrast, Strategy C was simply developed from the D-ANP method because most of Jesse Livermore's variables (uptrend/ downtrend) were not recognized as key factors by the 12 financial experts. Next, 10 pre-test transactions were conducted in the period from 2013 to 2014 using all three strategies, and Strategy $\mathrm{C}$ was found to be the only effective strategy because its WP exceeded 50\% (60\%). Strategies A and $\mathrm{B}$ were abandoned because their WPs were less than $50 \%(30 \%)$.

Strategy C performed better than Strategies A and B, but the conditions that must be satisfied to implement Strategy $\mathrm{C}$ raised eight problems. Therefore, eight adjustments were made to Strategy C to obtain the amended Strategy C. The amended Strategy $\mathrm{C}$ was implemented for the period from 2013 to 2014 and the empirical results demonstrated that the amended Strategy $\mathrm{C}$ performed better than the original Strategy C with a WP of $75 \%$, which exceeded that for the original Strategy C (60\%). The WP for the amended Strategy $\mathrm{C}$ was $57 \%$ during the period from January 1, 2015 to June 30,2015 , thereby suggesting that the amended Strategy C was still effective for the first half of 2015.

Thus, our empirical findings demonstrated that the amended Strategy C outperformed TAIEX futures in both the pre-test period ("2,621" points vs. "1,561" points) and the test period (" 455 " points vs. "-27" points). Therefore, we conclude that the amended Strategy $\mathrm{C}$ was the most effective among the three strategies considered in this study.

\section{REFERENCES}

[1] Bessembinder, Hendrik and Kalok Chan (1995). "The Profitability of Technical Trading Rules in the Asian Stock Markets," Pacific Basin Finance Journal, Vol. 3, 257-284.

[2] Boik, John (2004). Lessons from the Greatest Stock Traders of All Time. New York: McGraw - Hill Co.

[3] Boik, John (2006). How Legendary Trader Made Millions. New York: McGraw-Hill Co.

[4] Brock, William, Josef La konishok and Blake Le Baron (1992). "Simple Technical Trading Rules and the stochastic Properties of Stock Returns." Journal of Finance, Vol. 47, 1731-1764.
[5] Chiu, W. Y., G. H. Tzeng and H. L. Li (2013).”A New Hybrid MCDM Model Combining DANP with VIKOR to Improve E-store Business," Knowledge-Based Systems, Vol. 37, 48-61.

[6] Chiu, Wan-Yu, Gwo-Hsiung Tzeng and Han-Lin Li (2013). "A New Hybrid MCDM Model Combining DANP with VIKOR to improve E-Store Business" Knowledge-Based Systems, Vol. 37, January, 48-61.

[7] Chung, S. H., A. H. I. Lee and W. L. Pearn (2005). “Analytic Network Process (ANP) Approach for Product Mix Planning in Semiconductor Febeicator" International Journal of Production Economics, Vol. 96, No. 1, 15-36.

[8] Coulter, K and J. Sarkis (2005). "Development of a Media Selection Model Using the Analytic Network Process" International Journal of Advertising, Vol. 24, No.2, 193-216.

[9] Faith, Curtis M. (2007). Way of the Turtle: The Secret Methods That Turned Ordinary People into Legendary Traders. New York: McGraw-Hill Co.

[10] Fontela E. and A. Gabus (1976). "The DEMATEL Observer, DEMATEL 1976 Report," Battelle Geneva Research Center, Switzerland.

[11] Gabus, A. and E. Fontela (1972). "World Problems an Invitation to Further Thought within the Framework of DEMATEL" Battle Geneva Research Center, Switzerland.

[12] Gabus, A. and E. Fontela (1973). "Perceptions of the World Problematique: Communicating with those Bearing Collective Responsibility (DEMATE Report No.1) "Battelle Geneva Research Center, Switzerland.

[13] Görener, Ali (2012). "Comparing AHP and ANP: An Application of Strategic Decisions Making in a Manufacturing Company", International Journal of Business and Social Science, Vol. 3, No.11, June, 194-208.

[14] Herat, Ali T., Rassol Noorossana, Sahar Parsa and Elahe S. Serkani (2012). "Using DEMATEL-Analytic Network Process (ANP) Hybrid Algorithm Approach for Selecting Improvement Projects of Iranian Excellence Model in Healthcare", African Journal of Business Management, Vol. 6, No. 2, 627-645.

[15] Ho, Wen-Rong J., Chih-Lung Tsai, Gwo-Hsiung Tzeng, and Sheng-Kai Fang. "Combined DEMATEL Technique with a Novel MCDM Model for Exploring Portfolio Selection Based on CAPM," Expert Systems with Applications, Vol. 38, No.1, January, 16-25.

[16] Hori, S. and Y. Shimizu (1999). "Designing Methods of Human Interface for Supervisory Control Systems," Control Engineering Practice, Vol. 7, No. 11, 1413-1419.

[17] $\mathrm{Hu}$, Y. C. and J. F. Tsai (2006)."Backpropagation Multi -layer Perception for Incomplete Pairwise Comparison Matrices in Analytic Hierarchy Process", Applied Mathematics and Computation, Vol. 180. No. 1, 53-62.

[18] Hu, Y. C. (2010).'Analytic Network Process for Patten Classification Problems Using Genetic Algorithms, "Information Sciences, Vol. 180, No.13, 2528-2539.

[19] Hu, Y. C., Y. J. Chiu, C. S. Hsu, and Y. Y. Chang (2015). "Identifying Key Factors for Introducing GPS-Based Fleet Management Systems to the Logistics Industry" Mathematical Problems in Engineering, Article ID 413203, Hindawi Publishing Corporation. 
[20] Kahraman, C., T. Ertay and G. Buyukozkan (2006). “A Fuzzy Optimization Model for QFD Planning Process Using Analytical Network Approach," European Journal of Operational Research, Vol. 171, No. 2, 390-411.

[21] Kinosita, E. (2003). "From AHP to ANP," Operations Research of Japan, Vol. 48, No.9 677-683.

[22] Leung, L. C., Y. V. Hui, and M. Zheng (2003). "Analysis of Compatibility between Interdependent Matrices in ANP." Journal of Operational Research Society, Vol. 54, No.7, 758-768.

[23] Li, Chung-Wei and Gwo-Hsiung Tzeng (2009). "Identification of a Threshold Value for the DEMATEL Method: Using the Maximum Mean De-Entropy Algorithm", Communications in Computer and Information Science, Vol.35, 789-796.

[24] Livermore, Jesse. L. (1940). "How to Trade in Stocks." Greenville, South Carolina.: Trader Press.

[25] Meade, L. M. and J. Sarkis (1999). "Analyzing Organizational Project Alternatives for Agile Manufacturing Process: An Analytic Network Approach", International Journal of Production Research, Vol. 37, No. 2, 241-261.

[26] Meade, L. M. and A. Presley (2002). "R\&D Project Selection Using the Analytic Network Process." IEEE Transactions on Engineering Management, Vol. 49, No.1, 59-66.

[27] Niemira, M. P. and T. L. Saaty (2004). “An Analytic Network Process Model for

[28] Financial-Crisis Forecasting." International Journal of Forecasting, Vol. 20, No.4, 573-587.

[29] Ou Yang, Yu-Ping, How-Ming Shieh, Jun-der Leu and Gwo-Hsiung Tzeng (2008)."A Novel Hybrid MCDM Model Combined with DEMATEL and ANP with Applications", International Journal of Operations Research, Vol. 5, No. 3, 160-168.

[30] Ou Yang, Yu-Ping, How-Ming Shieh, and Gwo-Hsiung Tzeng (2013), "A VIKOR Technique Based on DEMATEL and ANP for Information Security Risk Controll Assessment," Information Sciences, Vol. 232, May 20, 482-500.

[31] Satty, Thomas L. and M. Takizawa (1986). "Dependence and Independence: From Linear Hiarchies to Nonlinear Networks, European Journal of Operational Research, Vol. 26, 229-237.

[32] Saaty, Thomas L. (1996). The Analytic Network Process-Decision Making with Dependence and Feedback. Pittsburgh, PA: RWS Publications.

[33] Saaty, Thomas L. (2001), Decision Making with Dependence and Feedback: The Analytic Network Process, Pittsburgh: RWS Publication.

[34] Saaty, Thomas L. (2005). Theory and Applications of the Analytic Network Process Decision Making with Benefits, Opportunities, Costs and Risks. Pittsburgh, Pennsulvania: RSW Publications.

[35] Saaty, Thomas L., and M.S. Özdemir (2005). The Encyclion: A Dictionary of Decisions with Dependence and Feedback Based on the Analytic Network Process, Pittsburgh: RWS Publications.

[36] Saaty, Thomas L., and Luis G. Vargas (2006). Decision Making with the Analytic Network Process: Economic,
Political, Social and Technological Applications with Benefits, Opportunities, Costs and Risks. New York: Springer.

[37] Sekitani, K and I. Takahashi (2001)."A Unified Model and Analysis for AHP and ANP," Journal of the Operational Research Society of Japan, Vol. 44, No.1, 67.

[38] Shee, D. Y., G. H. Tzeng and T. I. Tang (2003). “AHP, Fuzzy Measure and Fuzzy Integral Approaches for the Appraisal of Information Service Providers in Taiwan." Journal of Global Information Technology Management, Vol. 6, No. 1, 8-30.

[39] Shieh, Jiunn-I, Hsin-Hung Wu and Kuan-kai Huang (2010), "A DEMATEL Method in Identifying Key Success Factors of Hospital Service Quality," Knowledge-Based Systems, Vol. 23, No. 3, April, 277-282.

[40] Smitten, Richard (2001). Jesse Livermore: World's Greatest Stock Trader. New York: John Wiley and Sons.

[41] Tesfamuriam, D. and B. Lindberg (2005). "Aggregate Analysis of Manufacturing Systems Using System Dynamics and ANP." Computers and Industrial Engineering, Vol. 49, No. $1,98-117$.

[42] Tzeng, Gwo- Hsiung, Cheng-Hsin Chiang and Chung-Wei Li (2007). "Evaluate Intertwined Effects in E-learning Programs: A Novel Hybrid MCDM Model Based on Factor Analysis and DEMATEL", Expert Systems with Applications, Vol.32, 1028-1044.

[43] Tzeng, Gwo- Hsiung and Jih-Jeng Huang (2011). Multiple Attribute Decision Making: Methods and Applications. Boca Raton, Florida: CRC Press.

[44] Vujanović, Davor, Vladmir Momčilović, Nebojša Bojović, Vladimir Papić (2012). "Evaluation of Vehicle Fleet Maintenance Management Indicators by Application of DEMATEL and ANP," Expert Systems with Applications, Vol. 39, No.12. September, 10552-10563.

[45] Wang, Yung-Lan and Gwo-Hsiung Tzeng (2012). "Brand Marketing for Creating Brand Value Based on a MCDM Model Combining DEMATEL with ANP and VIKOR Methods," Expert Systems with Applications, Vol. 39, No. 5, April, 5600-5615.

[46] Wu, Wei-Wen (2008). "Choosing Knowledge Management Strategies by Using a Combined ANP and DEMATEL Approach.” Experts Systems with Applications, Vol. 35, No. 3, October, 828-835.

[47] Xu, Z and C. Wei (1999).”A Consistency Improving Method in the Analytic Hierarchy Process,"European Journal of Operational Research, Vol. 116, No. 2, 443-449.

[48] Yang, Jiann-Liang and Kwo-Hsiung Tzeng (2011), “An Integrated MCDM Technique Combined with DEMATEL for a Novel Cluster-Weighted with ANP Method," Expert Systems with Application, Vol. 38, No. 3, March, 1417-1424.

[49] Yüksel, Î. And M. Dağdeviren (2007). "Using the analytic Network Process (ANP) in a SWOT Analysis - A Case Study for the Textile Firm," Informalim Sciences, Vol. 177, No. 16, 3364-3382.

[50] Yurdakul, M. (2004). "AHP as a Strategic Decision-Making Tool to Justify Machine Tool Selection”, Journal of Materials Processing Technology, Vol. 146, No. 3, 365-376. 